\title{
Inositol lipid synthesis is widespread in host-associated Bacteroidetes
}

\author{
S. L. Heaver ${ }^{1}$, H. H. Le ${ }^{2}$, P. Tang ${ }^{3}$, A. Baslé ${ }^{4}$, J. Marles-Wright ${ }^{5}$, E. L. Johnson'², D. J. \\ Campopiano $^{3}$, R. E. Ley ${ }^{1}$
}

\author{
${ }^{1}$ Department of Microbiome Science, Max Planck Institute for Developmental Biology, Tübingen \\ 72076, Germany \\ ${ }^{2}$ Division of Nutritional Sciences, Cornell University, Ithaca, NY 14853, USA \\ ${ }^{3}$ School of Chemistry, University of Edinburgh, Edinburgh, Scotland, UK \\ ${ }^{4}$ Newcastle University Biosciences Institute, Newcastle University, UK \\ ${ }^{5}$ School of Natural and Environmental Sciences, Newcastle University, UK
}

\section{Abstract}

Ubiquitous in eukaryotes, inositol lipids have finely tuned roles in cellular signaling and membrane homeostasis. In Bacteria, however, inositol lipid production is rare. Recently, the prominent human gut bacterium Bacteroides thetaiotaomicron (BT) was reported to produce inositol lipids, including inositol sphingolipids, but the pathways remain ambiguous and their prevalence unclear. Here, we investigated the gene cluster responsible for inositol lipid synthesis in BT using a novel strain with inducible control of sphingolipid synthesis. We characterized the biosynthetic pathway from myo-inositol-phosphate (MIP) synthesis to phosphoinositol-dihydroceramide, including structural and kinetic studies of the enzyme MIP synthase (MIPS). We determined the crystal structure of recombinant BT MIPS with bound NAD cofactor at $2.0 \AA$ resolution, and identified the first reported phosphatase for the conversion of bacterially-derived phosphatidylinositol phosphate (PIP) to phosphatidylinositol (PI). Transcriptomic analysis indicated inositol production is nonessential but its loss alters BT capsule expression. Bioinformatic and lipidomic comparisons of Bacteroidetes species revealed a novel second putative pathway for bacterial PI synthesis without a PIP intermediate. Our results indicate that inositol sphingolipid production, via one of the two 
bioRxiv preprint doi: https://doi.org/10.1101/2021.04.26.441525; this version posted April 27, 2021. The copyright holder for this preprint (which was not certified by peer review) is the author/funder, who has granted bioRxiv a license to display the preprint in perpetuity. It is made available under aCC-BY-NC 4.0 International license.

pathways, is widespread in host-associated Bacteroidetes, and may be implicated in host interactions both indirectly via the capsule and directly through inositol lipid provisioning. 
Introduction

2

Inositol, a carbocyclic sugar abundant in eukaryotes, forms the structural basis for diverse

3 phosphorylated secondary messenger inositol phosphates and inositol lipids. At their simplest, inositol lipids have inositol as their polar headgroup, as is the case with phosphatidylinositol (PI; on a glycerophospholipid backbone) or inositol phosphorylceramide (on a sphingolipid backbone; Fig. 1A). multiple sites to form bioactive phosphoinositides, or the addition of a mannose on inositol sphingolipids to form the mannosylinositol phosphorylceramides (MIPCs) abundant in yeast ${ }^{1,2}$. Inositol derivatives control key processes of eukaryotic cell physiology. For instance, although phosphoinositides constitute a small fraction of overall phospholipids, they are ubiquitous and essential in roles such as marking organelle identity, regulating cytoskeleton-membrane interactions, and controlling cell division and autophagy ${ }^{3,4}$. membrane molecules to which surface oligosaccharide virulence factors are linked ${ }^{9}$.

backbone) and inositol lipids are involved in the regulation of cell fate and differentiation, inflammation, protein trafficking, and gene regulation in central metabolic pathways, with imbalances linked with the pathologies of a growing inventory of diseases ${ }^{4,10-12}$. These two lipid types intersect in the inositol sphingolipids, such as the glycosylinositol phosphorylceramides abundant in yeast and plants. Inositol SLs are known to be produced by the periodontal pathogen 
inositol SLs in the common human gut commensal Bacteroides thetaiotaomicron ${ }^{14}$. Ceramide phosphoryl-myo-inositol has been reported in Sphingobacterium spiritivorum ${ }^{15}$, a free-living member of the Bacteroidetes, and more recently in Myxococcus xanthus ${ }^{16}$, of the Proteobacteria phylum. In contrast to the well-studied inositol lipids, including inositol SLs, in plants and fungi, bacterial inositol sphingolipid synthesis has been largely overlooked.

The discovery of inositol lipids in a several more species suggests that these lipids may be more widespread in bacteria than previously thought and may use novel pathways. Across kingdoms, de novo inositol synthesis begins with the formation of inositol phosphate from glucose 6-phosphate (G6P) by a myo-inositol phosphate synthase (MIPS, EC 5.5.1.4) ${ }^{11}$. From here, a bacterial pathway for inositol glycerophospholipid synthesis is mostly known (e.g., in Mycobacteria), and differs from the eukaryotic pathway by the direct use of inositol-phosphate, not its dephosphorylated inositol form, as a substrate in the formation of PI. This leads first to the synthesis of phosphatidylinositolphosphate (PIP) from CDP-diacylglycerol (CDP-DAG) and MIP, which is subsequently dephosphorylated to $\mathrm{PI}^{17}$. Though the PIP synthase has been well characterized in bacteria ${ }^{18}$, the phosphatase responsible for the conversion of bacterial PIP to PI has not yet been identified ${ }^{18}$. In addition, though the gene cluster for bacterial inositol SL synthesis has been predicted in $B$. thetaiotaomicron (hereafter BT) ${ }^{14}$, the functions of these enzymes remain to be confirmed. Here, we combine genomic and biochemical approaches to functionally characterize the predicted inositol lipid metabolism gene cluster in BT from the initial synthesis of myo-inositolphosphate (MIP) to its addition as a headgroup to glycerophospholipids and SLs. Together with the description of a novel putative alternative gene cluster, common in the Prevotella, this work broadens the understanding of how gut bacteria synthesize complex lipids, and reveals an extensive capacity for inositol lipid synthesis among gut-associated Bacteroidetes. 
bioRxiv preprint doi: https://doi org/10.1101/2021.04 26.441525; this version posted April 27, 2021. The copyright holder for this preprint (which was not certified by peer review) is the author/funder, who has granted bioRxiv a license to display the preprint in perpetuity. It is made available under aCC-BY-NC 4.0 International license.

54

55

56

57

58

59

60

61

62

63

64

65

\section{$\underline{\text { Results and Discussion }}$}

We first identified genes responsible for inositol lipid metabolism in BT (Fig. 1A). We

identified BT_1522 by NCBI Blast-P as having high homology to the yeast enzyme inositol

phosphorylceramide synthase (IPC synthase, also known as AUR1) that catalyzes the attachment of

the phophorylinositol group onto ceramide (query cover 50\%, e-value 1e-15, percent identity $26 \%$ ).

This led us to hypothesize that this enzyme is responsible for phosphoinositol SL synthesis in BT,

though BT SLs have predominantly dihydroceramide (not ceramide) backbones, leading instead to

the synthesis of phosphoinositol dihydroceramide (PI-DHC). BT_1522 and its gene cluster (Fig. 1B)

were previously predicted to be involved in inositol lipid metabolism ${ }^{14}$. Adjacent predicted genes in

the cluster include BT_1523 (annotated as a CDP-diacylglycerol-inositol 3-phosphatidyltransferase),

BT_1524 (hypothetical protein), BT_1525 (currently annotated as phosphatidylglycerophosphatase A,

PgpA), and BT_1526 (myo-inositol phosphate synthase, "MIPS").

A

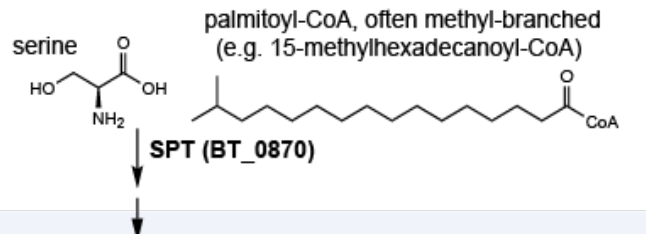

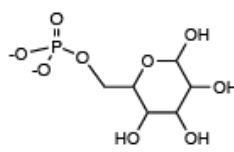

glucose-6-P
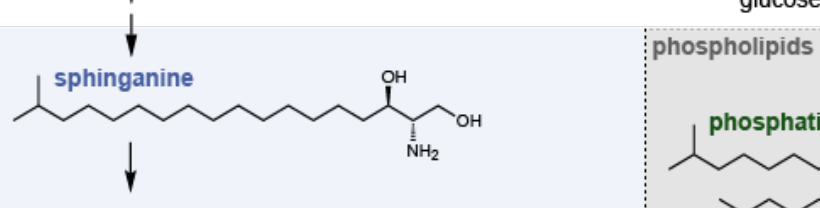

Y

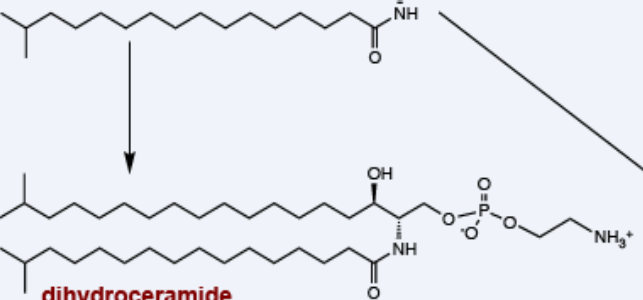

dihydroceramide

phosphoethanolamine

sphingolipids

$\mid \mathrm{PIPh}$

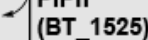

$r$

(BT_1522)
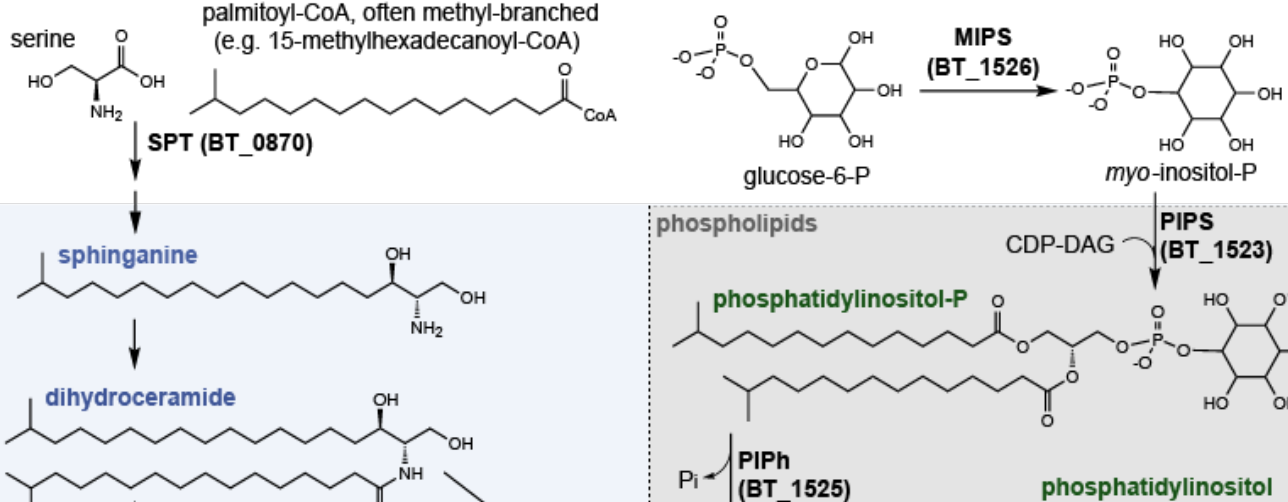

myo-inositol-P

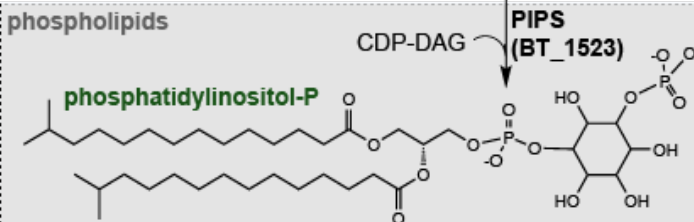

phosphatidylinositol

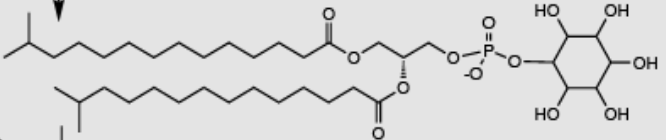

PI-DHC synthase

phosphoinositol

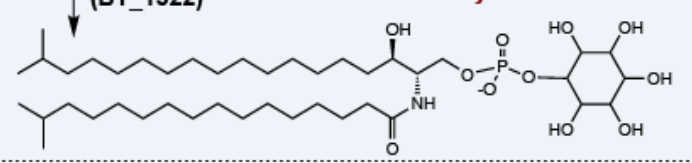

B

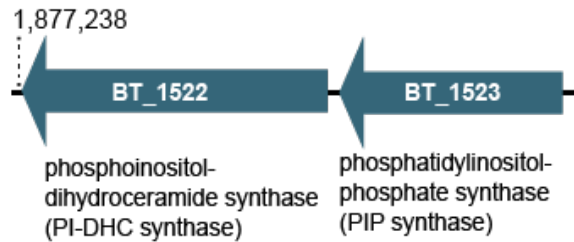

$1,881,296$ 
bioRxiv preprint doi: https://doi.org/10.1101/2021.04.26.441525; this version posted April 27, 2021. The copyright holder for this preprint (which was not certified by peer review) is the author/funder, who has granted bioRxiv a license to display the preprint in perpetuity. It is made available under aCC-BY-NC 4.0 International license.

Figure 1. Enzymatic pathway for inositol lipid synthesis in BT. (A) The de novo sphingolipid synthesis metabolic pathway in relation to inositol lipid synthesis, with BT enzymes investigated in this study (bolded black) and representative lipid structures. Sphingolipid structures are on a light blue background; phospholipid structures are on a gray background. (B) The genomic region of BT inositol and inositol lipid synthesis. Gene color (blue or red) indicates membership in an operon predicted by BioCyc. Annotations are of the enzyme functions elucidated in this study (due to the lack of a lipid phenotype in its knockout strain, BT_1524 was not investigated further and remains hypothetical).
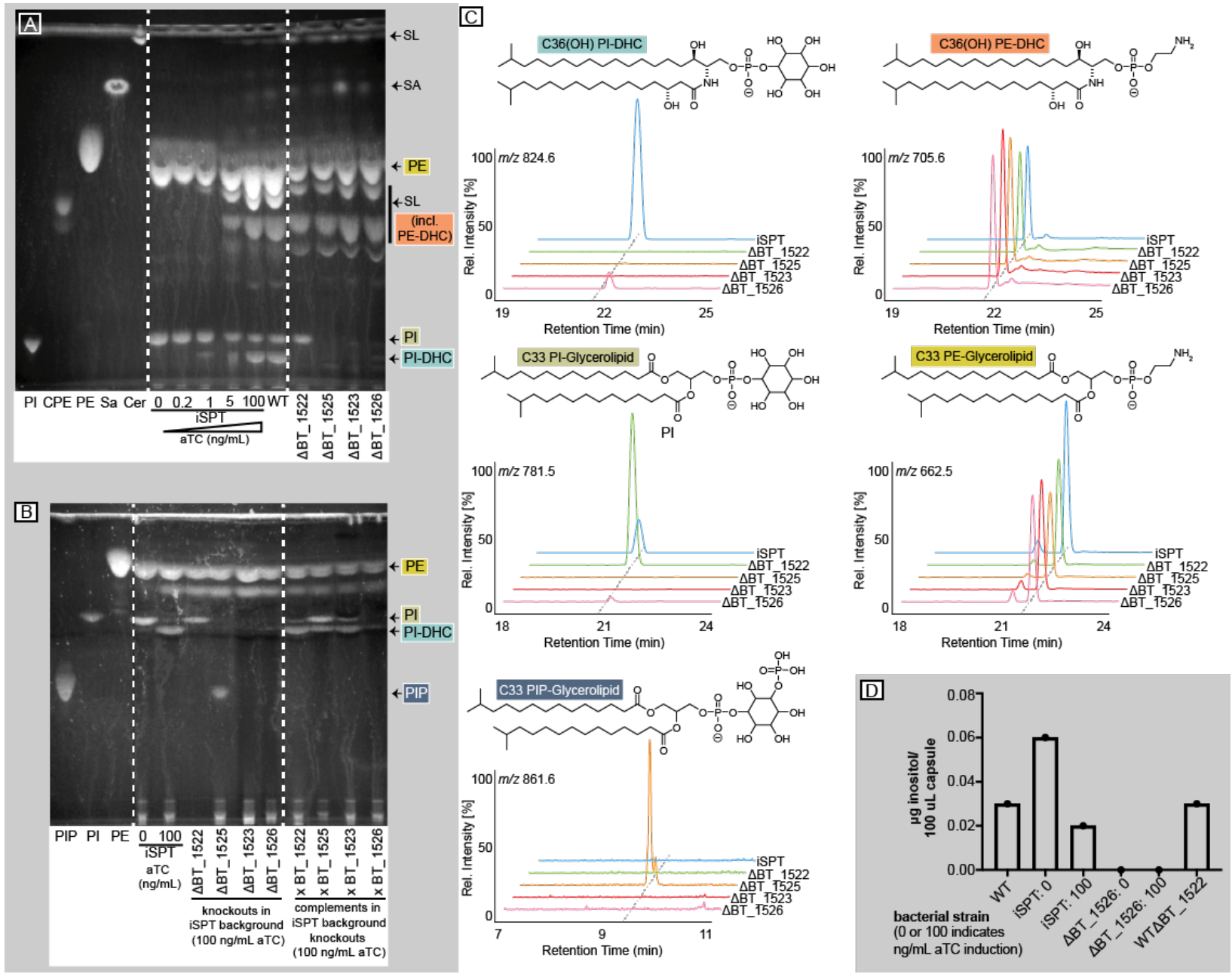

Figure 2. BT produces inositol phospholipids and sphingolipids. (A) Thin layer chromatography (TLC) of left to right: first section indicated by dashed lines includes five standards: $\mathrm{PI}=16: 0$ phosphatidylinositol; PIP = 18:1 PI(3)P; CPE = ceramide phosphoethanolamine; $\mathrm{PE}=$ egg yolk phosphatidylethanolamine, $\mathrm{Sa}=\mathrm{d} 18: 0$ sphinganine, $\mathrm{Cer}=\mathrm{d} 18: 1 / 18: 0$ ceramide; second section includes six standard (non-acidic) lipid extracts from the iSPT BT strain (used as a background for knockout generation) at $0,0.2,1,5$ and $100 \mathrm{ng} / \mathrm{mL}$ aTC induction of SPT, and WT BT VPI-5482; third section includes standard lipid extraction from $\triangle B T \_1522, \triangle B T \_1523, \Delta B T \_1525$, and $\triangle B T$ 1526 knockout strains in the iSPT background at $100 \mathrm{ng} / \mathrm{mL}$ aTC induction of SPT. (B) TLC of: standards (PIP, PI, PE) as in panel $\mathrm{A}$; second section shows PIP lipid extractions of iSPT strains at 0 and 100 $\mathrm{ng} / \mathrm{mL}$ aTC followed by $\triangle \mathrm{BT} \_1522, \Delta \mathrm{BT} \_1523, \Delta \mathrm{BT} \_1525, \Delta \mathrm{BT} \_1526$, and each of their respective complementations (all strains in the iSPT background) at $100 \mathrm{ng} / \mathrm{mL}$ aTC induction of SPT. (C) Predicted structures and ion chromatograms demonstrating detection of inositol lipids and sphingolipids in iSPT, $\triangle B T \_1522, \triangle B T \_1523, \triangle B T \_1525$, and $\triangle B$ BT_1526 (all strains in the iSPT background) at $100 \mathrm{ng} / \mathrm{mL}$ aTC induction. (D) Quantification of inositol in the capsule of BT strains 
with or without sphingolipids (iSPT 100 vs. $0 \mathrm{ng} / \mathrm{mL}$ aTC induction), PI-DHC synthase (WTABT_1522), and MIPS ( $\triangle B$ BT_1526, at 0 and $100 \mathrm{ng} / \mathrm{mL}$ aTC induction).

We next constructed a BT strain with tunable SL synthesis. As inositol lipids in BT include both glycerophospholipids (PI) and SLs (PI-DHC), we created a strain of BT with inducible control of the first enzyme in the de novo SL synthesis pathway, serine palmitoyltransferase (SPT; BT_0870; Fig. 1) ${ }^{19}$. This inducible-SPT (“iSPT”) strain enables precise control over BT synthesis to produce both PI and PI-DHC, or solely PI. As expected, in the absence of SPT, we detected no SLs by thin-layer chromatography (TLC) analysis (Fig. 2A). However, in iSPT, SL synthesis gradually increased with increasing levels of the anhydrotetracycline (aTC) inducer, to an approximate wild-type (WT) SL abundance with $100 \mathrm{ng} / \mathrm{mL}$ aTC induction (Fig. 2A). At full induction, SLs composed roughly half of the extracted lipids measured by TLC densitometry $(47 \pm 7 \%, n=6)$. These SLs include PI-DHC and phosphoethanolamine dihydroceramide (PE-DHC), among others (Fig. 2C).

To uncover the function of each predicted enzyme in the putative inositol lipid metabolism pathway, we knocked out the individual genes (BT_1522 to BT_1526) in the iSPT background by scarless deletion ${ }^{20}$ (denoted $\Delta \mathrm{BT}$ _1522 to $\left.\Delta \mathrm{BT} \_1526\right)$. BT_1522 was also knocked out in the WT background (indicated by WT $\Delta$ BT_1522). We examined the lipid content of the resulting knockout strains (with SL synthesis fully induced) using TLC and HPLC-MS. Consistent with the predicted role for BT_1522 as a PI-DHC synthase, the $\triangle$ BT_1522 strain failed to produce PI-DHC, but production of $\mathrm{PI}$ and non-inositol SLs, including PE-DHC, was unaltered (Fig. 2A-C). Similarly, the $\Delta$ BT_1526 strain (lacking the predicted MIPS) failed to produce both PI and PI-DHC, in accordance with the loss of the myo-inositol-phosphate substrate.

Interestingly, both the $\Delta \mathrm{BT} \_1523$ and $\Delta \mathrm{BT} \_1525$ strains also failed to produce both PI and PIDHC (Fig. 2A). As the synthesis of other glycerophospholipids did not appear to be affected in the $\triangle B T \_1525$ strain, this observation was not in agreement with the annotated function of BT_1525 as a PgpA ${ }^{21}$. We hypothesized that BT may use a two-step process to synthesize PI similar to that found in Mycobacteria, which uses a PIP intermediate ${ }^{18}$. In accord, comparison of the functional protein 
motifs in BT_1523 and BT_1525 with those in the characterized Renobacterium salmoninarum PIP

synthase (PIPS) ${ }^{22}$ revealed the same conserved catalytic residues ( $\mathrm{DX}_{2} \mathrm{DGX}_{2} \mathrm{AR}$...GX $\left.{ }_{3} \mathrm{DX}{ }_{3} \mathrm{D}\right)$ in $\mathrm{BT} \_1523$.

This observation supports the notion that BT_1523 functions as a PIPS in the biosynthesis of PIP. protein motif from the dephosphorylation of a phospholipid glycerophosphate headgroup to an inositolphosphate headgroup. Previous work has shown that transcriptomic expression of $B T_{-} 1525$ is higher than $B T_{-} 1523$ and $B T_{-} 1522$ in every growth phase of $B T^{23}$, likely enabling the rapid conversion of PIP to PI and preventing accumulation of PIP in BT. mutant, we did not investigate it further.

To confirm that the loss of inositol lipids in knockout strains was not due to off-target effects,

140 the native BT sequence of each gene was integrated genomically into knockout strains in the iSPT

141 background ( $\left.\triangle \mathrm{BT} \_1522, \Delta \mathrm{BT} \_1523, \Delta \mathrm{BT} \_1525, \Delta \mathrm{BT} \_1526\right)$, paired with a constitutive promoter

142 optimized for $\mathrm{BT}^{27}$. The complementation was successful for three of the four strains ( $\triangle \mathrm{BT} \_1522$,

$143 \Delta \mathrm{BT}$ 1523, and $\triangle \mathrm{BT} \_$1525), fully restoring the capacity for both PI and PI-DHC synthesis (Fig. 2B). 
144

C
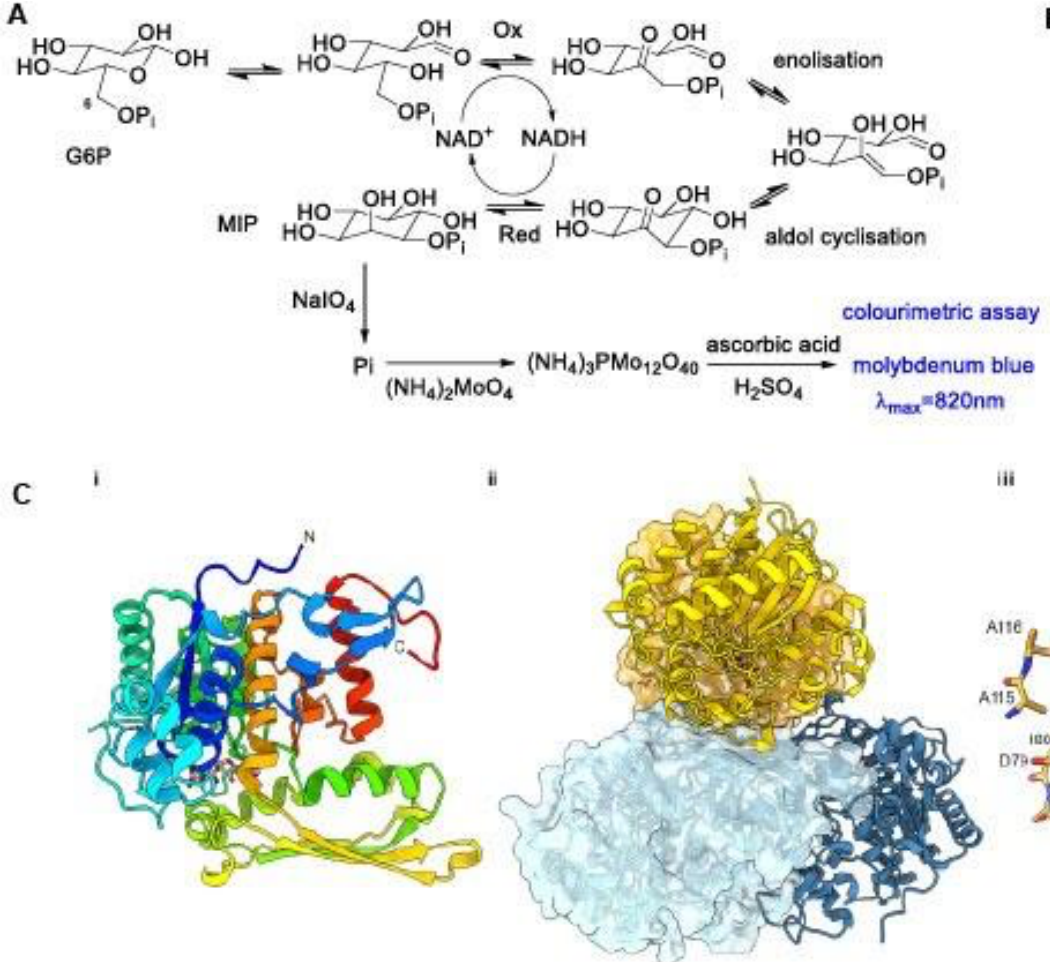
the MIPS:NAD complex.

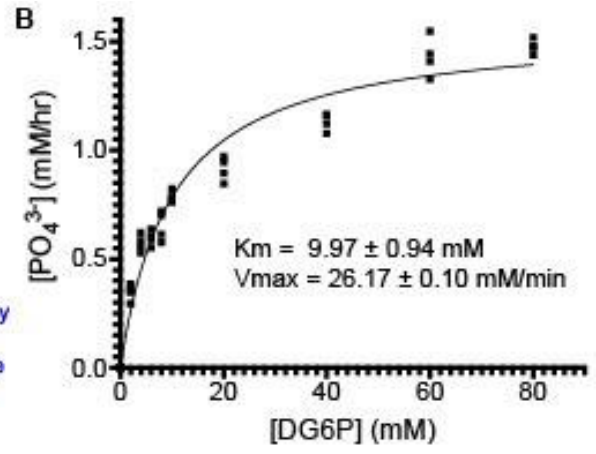

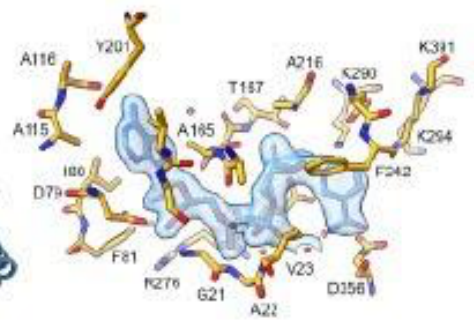

Figure 3. BT_1526 produces myo-inositol-phosphate in vitro. (A) Proposed mechanism for the MIPScatalyzed NAD-dependent/redox-neutral conversion of G6P to MIP. (B) Molybdenum blue assay for detection of MIP. Kinetic analysis of recombinant BT_1526 MIPS using G6P as substrate. (C) The crystal structure of BT_1526 MIPS: (i) The monomer subunit, (ii) the tetramer, (iii) the structure of

To confirm the predicted function of BT_1526 as a redox-neutral, NAD $/$ NADH-dependent

MIPS, we cloned the gene and heterologously overexpressed the protein in E. coli (Fig. 3 and

Supporting Information). The N-terminally His-tagged BT_1526 expressed well in a highly soluble

form ( $50 \mathrm{kDa}$ in size, observed by SDS-PAGE and confirmed by electrospray ionization mass

spectrometry, see $\mathrm{SI}$ ), and was purified to homogeneity by standard immobilized metal affinity

chromatography methods. The MIPS activity of BT_1526 was confirmed using a colorimetric

endpoint assay which monitors the appearance of the inorganic phosphate released from the MIP product and not the G6P substrate ${ }^{28}$ (Fig. 3A). Kinetic analysis of BT_1526 MIPS operating on G6P are as follows: $\mathrm{K}_{\mathrm{m}}=9.97 \pm 0.94 \mathrm{mM}, \mathrm{V}_{\max }=26.17 \pm 0.10 \mu \mathrm{M} / \mathrm{min}$, specific activity $=0.513 \mu \mathrm{mol} / \mathrm{min} / \mathrm{mg}$

160 (Fig. 3B). This activity is in the range of the published specific activities of MIPS from S. cerevisiae 

final structure contains an $\mathrm{NAD}^{+}$molecule associated with each chain modelled at unit occupancy.

174 Given the redox neutrality of the MIPS enzyme (i.e., it catalyzes substrate oxidation, then reduction)

175 there is a clear benefit to the retention of the $\mathrm{NAD}^{+}$in the active site for the lifetime of the protein, in agreement with NAD ${ }^{+}$retention in MIPS from other species ${ }^{37}$. The catalytic active site region of the protein is well conserved among members of the MIPS family for which a structure has been determined, with a cluster of lysine and aspartic acid residues responsible for binding and orienting the G6P substrate for isomerization to the MIP product, highlighting the importance of these residues for the correct activity of the enzyme. Outside of the highly conserved ligand binding site, elements of other MIPS enzymes, underscoring its conservation across biological kingdoms. 
bioRxiv preprint doi: https://doi.org/10.1101/2021.04 26.441525. this version posted April 27. 2021. The copvriaht holder for this preprint (which was not certified by peer review) is the author/funder, who has granted bioRxiv a license to display the preprint in perpetuity. It is made available under aCC-BY-NC 4.0 International license.

189

190

191

192

193

194

cell surface polysaccharides. Only 29 genes were differentially expressed with greater than 1.5

absolute $\log _{2}$-fold-change in the $\Delta \mathrm{BT} \_1526$ strain compared to the background iSPT strain at 100

$\mathrm{ng} / \mathrm{mL}$ induction of SPT. These genes were almost entirely involved in capsule biosynthesis (Table S3).

Expression of CPS loci was fairly uniform across varied levels of SPT induction in the iSPT strain, while

the $\triangle \mathrm{BT} \_1526$ strain had notable upregulation of capsular polysaccharide synthesis loci 1 and 6 (CPS1

and CPS6) (Fig. 4).

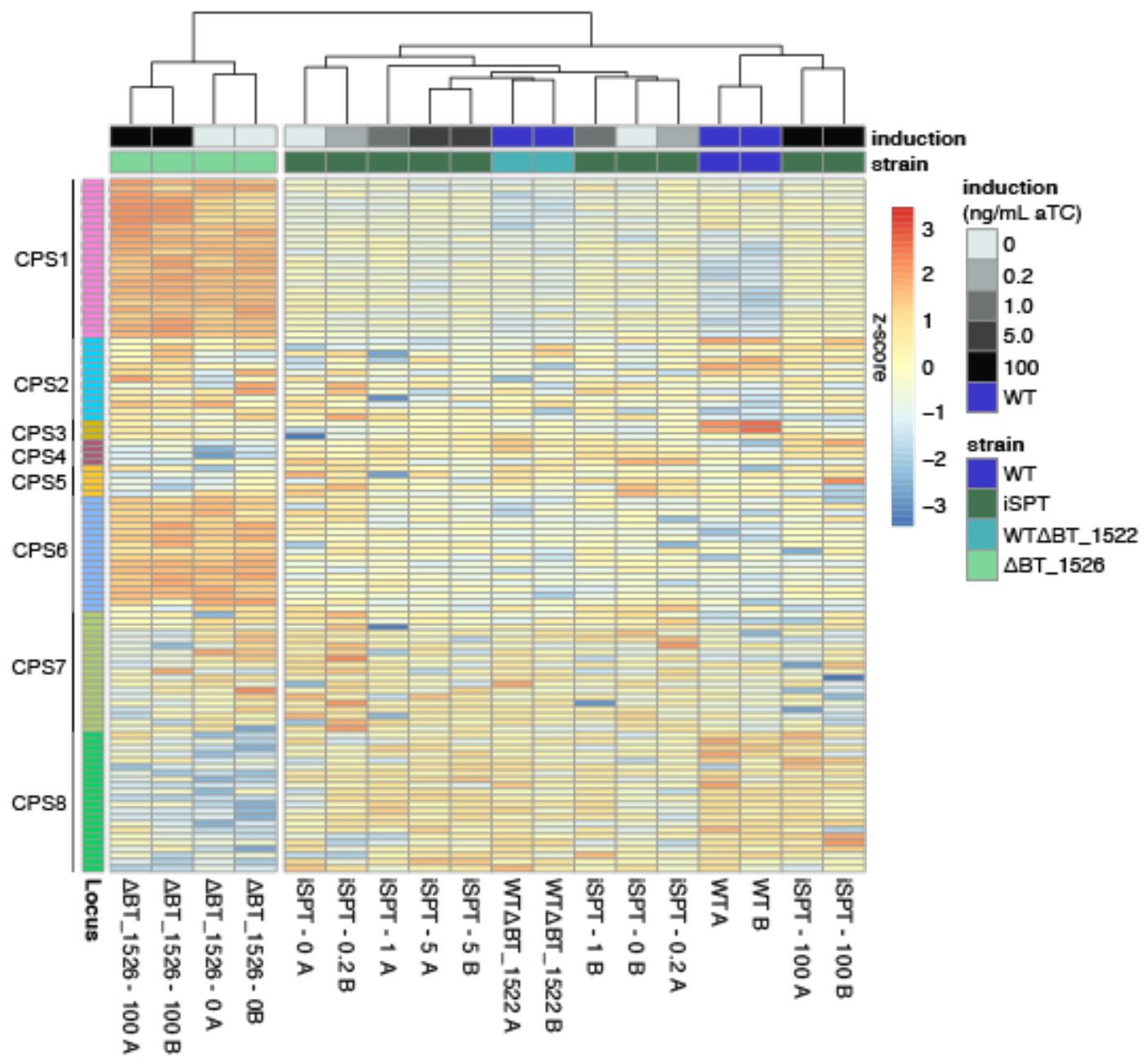

Figure 4. Deletion of MIPS (BT_1526) alters expression of genes for capsular polysaccharide

synthesis pathway loci in BT. Gene expression data (normalized $\log _{2}$ expression values, scaled by row, with Euclidean column clustering) in the 8 BT capsular polysaccharide synthesis (CPS) loci. For easier visualization, genes were filtered to include those in which maximum $\log _{2}$-normalized expression is $>1.5$ and exclude those with maximum absolute $\log _{2}$-fold-change difference in expression $<1.5$ in all pairwise comparisons of conditions. Color in the far left column indicates gene assignment to one of 8 CPS loci. Strains tested include WT BT, iSPT, WTABT_1522, and $\triangle B T$ 1526 in the iSPT background. SPT induction in the iSPT strains at $0,0.2,1.0,5.0$, or $100 \mathrm{ng} / \mathrm{mL}$ aTC induction is indicated in shades of grey. Labels below each column indicate strain and aTC induction level (ng/mL aTC) redundantly with the color key; " $A$ " and " $B$ " labels represent biological replicates. 

monitored the transcriptional response of WTABT_1522 at early stationary phase, grown in minimal medium with glucose as the sole carbon source. Compared to its BT background strain, the WTABT_1522 strain had differential expression of 37 genes above a cutoff of 1.5 absolute $\log _{2}$-foldphysiology, for example, protein anchoring and programmed cell death in plants ${ }^{38}$. The yeast homolog of BT_1522 is an antifungal target, highlighting its core function in yeast physiology, which is inhibited by the cyclic depsipeptide natural product aureobasidin (hence the name AUR1) ${ }^{39}$. Though WTABT_1522 had few transcriptomic changes relative to WT controls, its affected pathways appear central to carbohydrate degradation and energy synthesis. As such, other inositol derivatives or $\mathrm{PI}$, not $\mathrm{PI}-\mathrm{DHC}$, are implicated in the altered capsule expression of the $\Delta \mathrm{BT} \_1526$ strain. induced and -uninduced $\Delta \mathrm{BT} \_1526$ strains. To assess whether the transcriptional trend of the $\triangle B T \_1526$ to upregulate CPS1 and CPS6 was reflected in the visible cell capsule, we performed 230 scanning electron microscopy on iSPT and $\triangle \mathrm{BT} \_1526$ strains with and without SL induction (Fig. 5A).

231 Capsule structures were heterogeneous in both strains, but in comparison to the iSPT background strain, more of the cells of the $\Delta \mathrm{BT}$ _1526 strain exhibited a dense structure extending from the cell 
surface, with apparent exopolysaccharide connecting adjacent cells. This was particularly noticeable when SL synthesis was not induced. specificity in BT. The CPS loci expressed in a BT population influence both recognition by the host adaptive immune system and bacteriophage predation ${ }^{40,41}$. A role for SLs in mediating the role of inositol in host-BT interactions. Inositol SLs have only been described in few bacterial species to date ${ }^{14-16}$. We investigated the extent of this biosynthetic capacity across ten representative members of the phylum Bacteroidetes and in other known bacterial SL-producers. Using a homology cutoff of an e-value less than 1e-8, we compared the BT amino acid sequences for MIPS, PIPS, PIPh, PI-DHC synthase, and the BT InsP6 phosphatase, MINPP ${ }^{43}$ (BT_1526, BT_1523, BT_1525, BT_1522, and BT_4744, respectively) to these with homology to the BT MIPS and PI-DHC synthase had lipid bands consistent with PI and/or PI-DHC in line with their genomically-predicted capacity (the exception was Flectobacillus major, a

254 Proteobacterial species with genes encoding protein homology but that did not produce inositol 255 lipids under tested conditions). However, we were surprised to also observe lipid bands consistent 256 with the synthesis of PI and PI-DHC in species lacking homology to BT_1522/23/25. HPLC-MS analysis 
bioRxiv preprint doi: https://doi.org/10.1101/2021.04.26.441525; this version posted April 27, 2021. The copyright holder for this preprint (which was not certified by peer review) is the author/funder, who has granted bioRxiv a license to display the preprint in perpetuity. It is made available under aCC-BY-NC 4.0 International license.
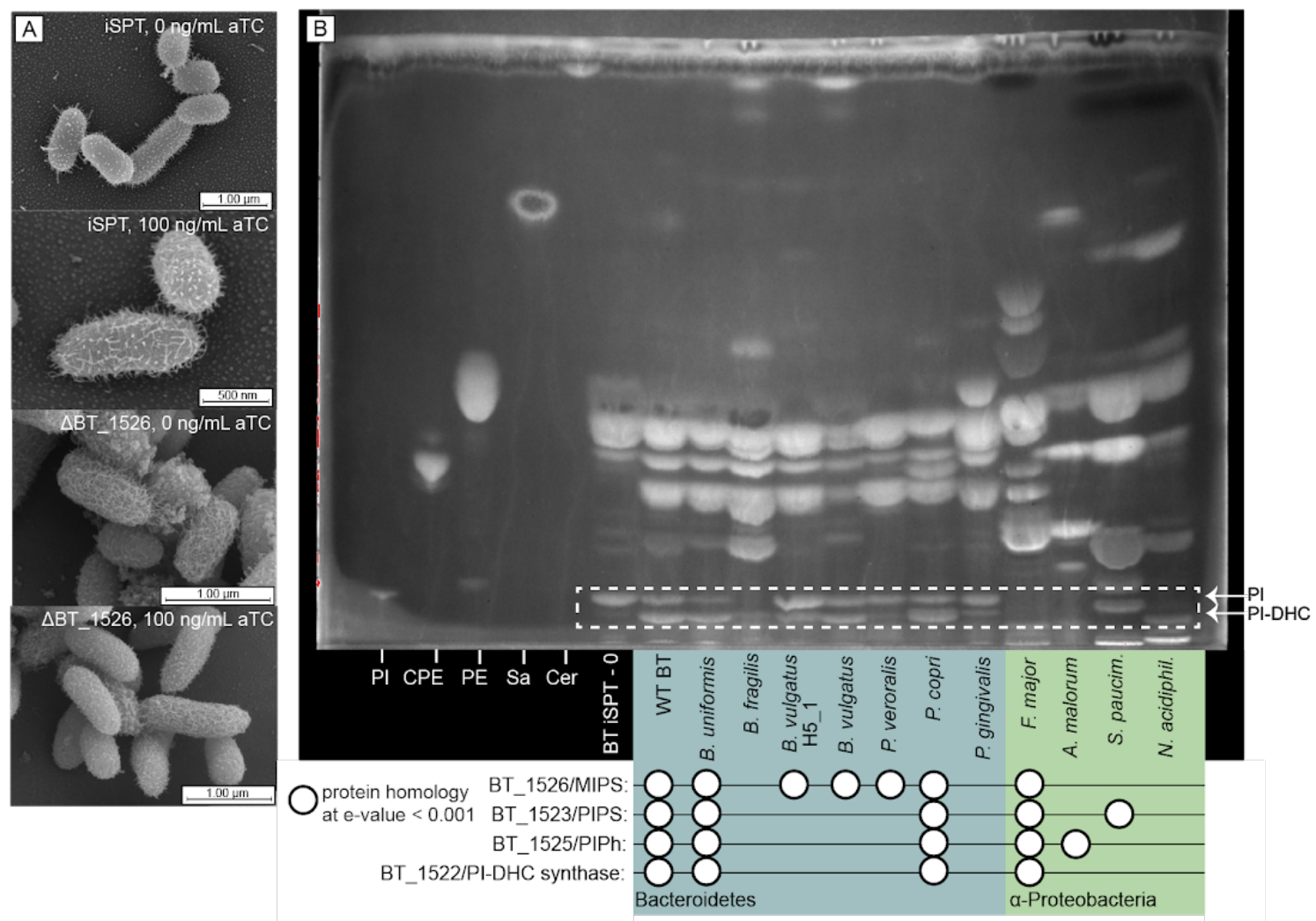

C
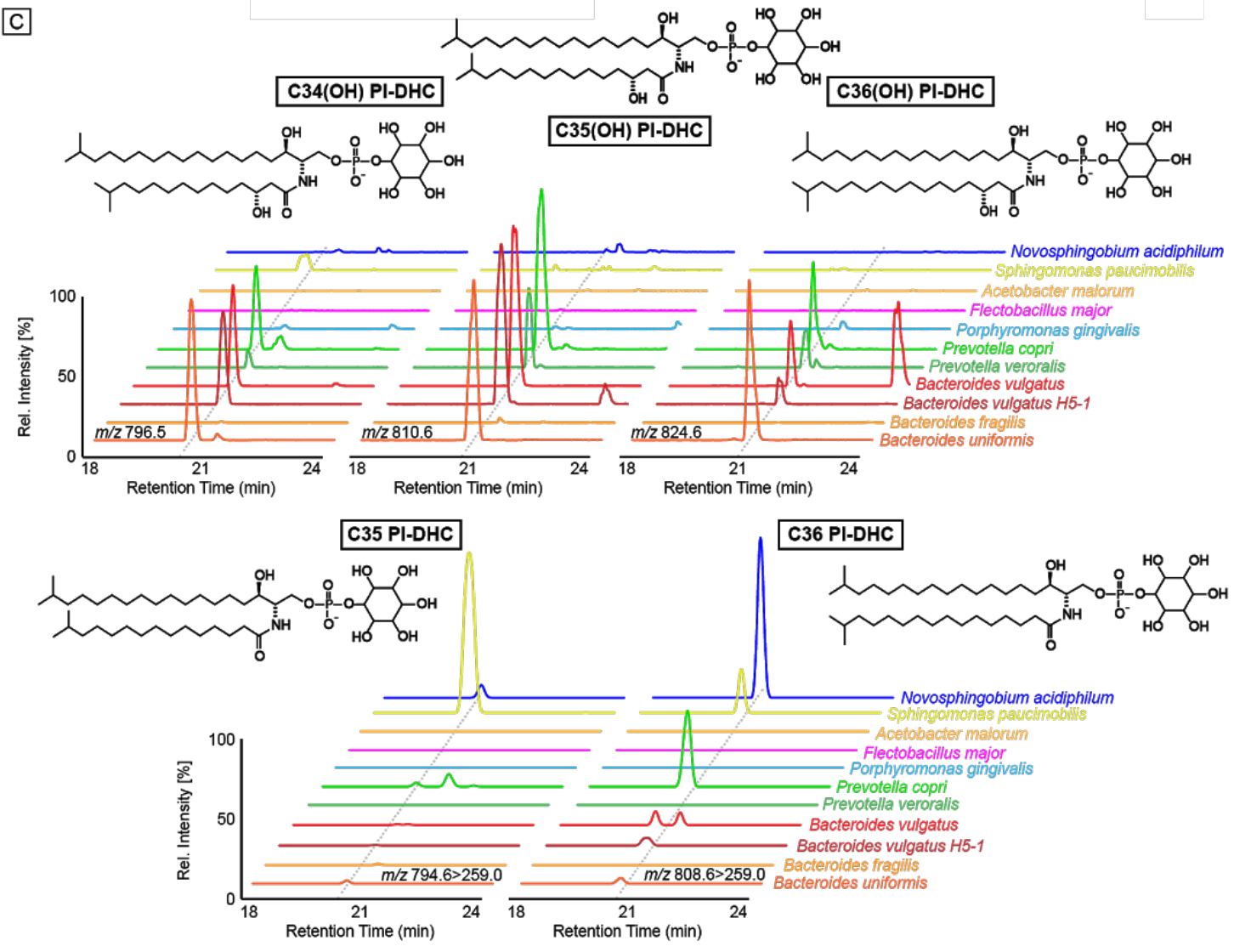
Figure 5. The capacity to produce PI-DHC is widespread among sphingolipid-producing bacteria. (A) Scanning electron microscopy of the iSPT and $\triangle B T \_1526$ strains at 0 and $100 \mathrm{ng} / \mathrm{mL}$ aTC induction of SPT grown in minimal medium. (B) TLC of lipid standards and lipid extractions from a diverse array of sphingolipid-producing bacteria. Lanes 1-5, left to right: $\mathrm{PI}=16: 0$ phosphatidylinositol; $\mathrm{CPE}=$ ceramide phosphoethanolamine; $\mathrm{PE}=$ egg yolk phosphatidylethanolamine, $\mathrm{Sa}=\mathrm{d} 18: 0$ sphinganine, Cer $=\mathrm{d} 18: 1 / 18: 0$ ceramide. From the sixth lane onward are standard Folch (non-acidic) lipid extractions from: BT iSPT $0 \mathrm{ng} / \mathrm{mL}$ aTC induction (no SL), WT BT, Bacteroides uniformis (DSM 6597), Bacteroides fragilis (DSM 2151), Bacteroides vulgatus H5_1 (DSM 108228), Bacteroides vulgatus (DSM 1447), Prevotella veroralis (ATCC 33779), Prevotella copri (DSM 18205), Porphyromonas gingivalis (DSM 20709), Flectobacillus major (DSM 103), Acetobacter malorum (DSM 14337), Sphingomonas paucimobilis (ATCC 29837), and Novosphingobium acidiphiulum (DSM 19966). Homology to BT protein sequences in the inositol lipid cluster using NCBI BlastP (at e-values below 0.001 ) are indicated below species names with a white circle. Bacteroidetes spp. are on a blue background; alpha-Proteobacteria spp. are on a green background. (C) Predicted structures and ion chromatograms of PI-DHC structures in lipids extracted from the diverse sphingolipid-producing species shown in the same order in panel $\mathrm{B}$. Phosphoinositol dihydroceramide structures include C34(OH) PI-DHC, C35(OH) PI-DHC, C36(OH) PI-DHC, C35 PI-DHC, and C36 PI-DHC.

To understand this unexpected result, we searched the genomes of related species

containing a BT_1526 (MIPS) homolog but lacking homology to the remainder of the BT cluster. Using

PHI-BLAST with the conserved catalytic residues in BT_1523 (DX $\left.\mathrm{DGGX}_{2} \mathrm{AR} \ldots \mathrm{GX}_{3} \mathrm{DX} \mathrm{X}_{3} \mathrm{D}\right){ }^{22}$, we identified a predicted CDP-alcohol phosphatidyltransferase in the vicinity of the MIPS homolog in Bacteroides vulgatus. Expanding the analysis to include other genomes from the Bacteroidetes, we observed that almost every Bacteroides/Prevotella species containing a MIPS homolog had one of two clusters directly in the vicinity of the MIPS gene - either the BT-like cluster (BT_1522/23/25), or an alternate cluster including an NTP transferase (nucleotidyltransferase) domain-containing protein, CDPalcohol-phosphatidyltransferase, and haloalkanoate dehalogenase (HAD) hydrolase (Fig. 6). The NTP transferase domain family protein (NCBI Conserved Domain Family cl11394) also shares homology with a phosphocholine cytidyltransferase motif, suggesting this protein may synthesize cytidine 5'diphosphoinositol (CDP-inositol), similar to the synthesis of CDP-inositol as a precursor to di-myoinositol phosphate solutes in hyperthermophiles ${ }^{44}$. The HAD hydrolase superfamily is large and diverse, with the majority of characterized members functioning as phosphotransferases ${ }^{45}$. As a lipid phosphate phosphohydrolase, this HAD hydrolase may function similarity to AUR $1^{46}$, acting as a PI- 

synthesis of PI-DHC without a PIP intermediate (similar to PI synthesis in eukaryotes ${ }^{47}$ ), with PI synthesis resembling the synthesis of phosphatidylethanolamine or phosphatidylcholine in the Kennedy pathway ${ }^{48,49}$. Following this logic, the NTP transferase protein would first synthesize CDPHAD hydrolase proteins are fused (Supp. Fig. 5), suggesting the possibility for a cohesive singleenzyme conversion of CDP-inositol to PI-DHC through a PI intermediate. Some additional putative enzymes are shared in the vicinity of both clusters, including genes annotated as a

307 lysylphosphatidylglycerol synthase (BT_1521 homolog) and a carboxypeptidase-regulatory-like domain protein (BT_1527 homolog) (Fig. 6). This alternative pathway could explain PI-DHC synthesis by $P$. veroralis and $B$. vulgatus despite lack of homology to the BT inositol lipid cluster (BT_1522/23/25). phosphorylglycerol-DHC (Supp. Fig. 2C) ${ }^{50}$. 
bioRxiv preprint doi: https://doi.org/10.1101/2021.04.26.441525; this version posted April 27, 2021. The copyright holder for this preprint (which was not certified by peer review) is the author/funder, who has granted bioRxiv a license to display the preprint in perpetuity. It is made available under aCC-BY-NC 4.0 International license.

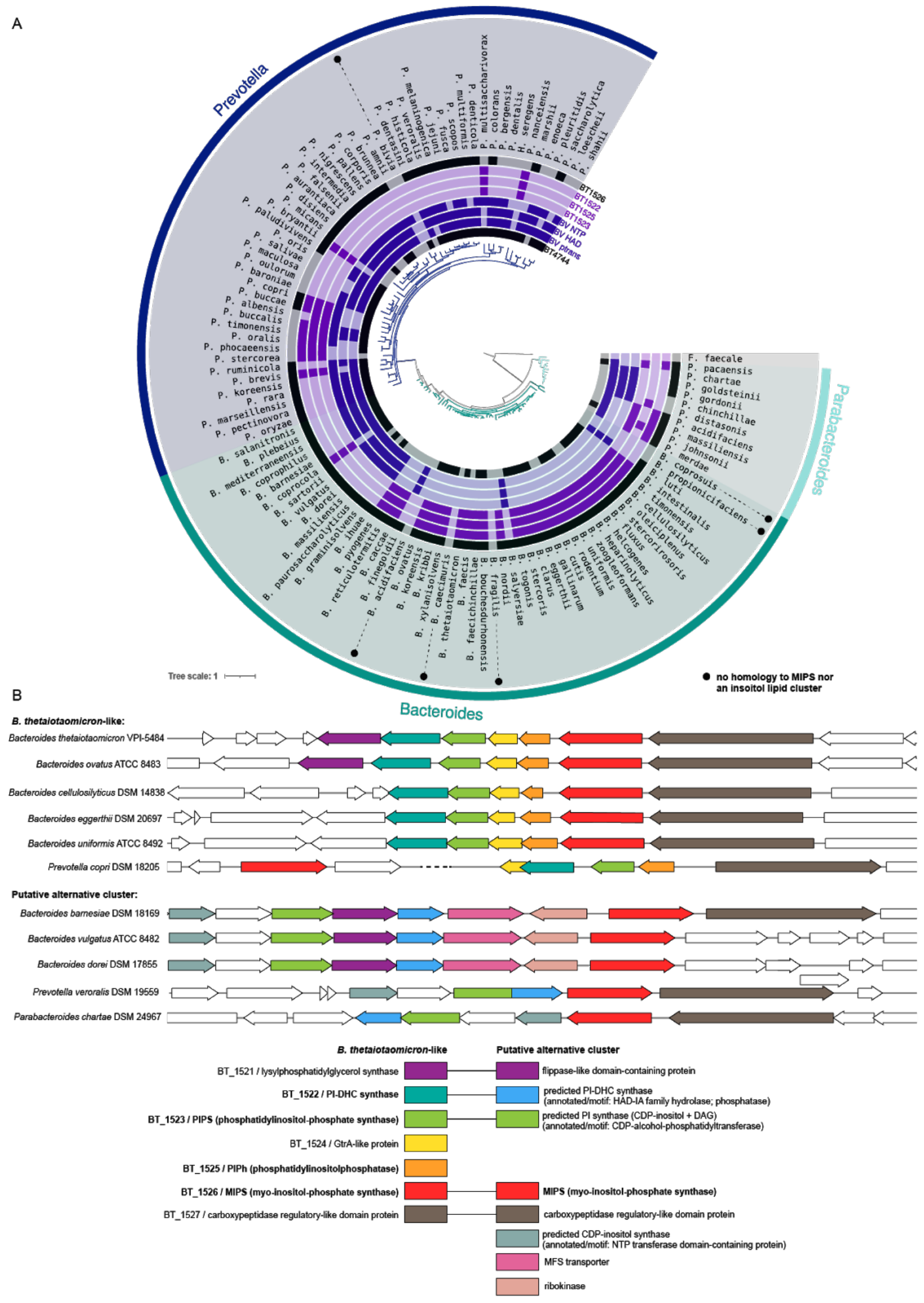

Figure 6. The capacity for inositol lipid synthesis is widespread within the Bacteroidetes. (A)

322 Maximum likelihood based phylogeny of representative Bacteroides, Prevotella, and Parabacteroides 
species, produced from 71 conserved single copy genes present in all genomes (identified and concatenated using Anvi'o), and generated by RAxML (best tree; substitution model PROTCAT, matrix name DAYHOFF, Hill-climbing algorithm, bootstrap 50); Flavobacterium faecale is included as an outgroup. The rings surrounding the tree indicate species with genes that have NCBI BlastP homology to the BT inositol lipid cluster (in light purple; BT_1522, BT_1523, BT_1525, BT_1526), the BT Minpp (BT_4744), or representative proteins from the Bacteroides vulgatus putative alternative inositol lipid cluster (in dark purple; phosphatidyltransferase: BVU_RS13105, HAD hydrolase: BVU_RS13115, NTP transferase: BVU_RS13095). Homology at an e-value below 1e-8 is indicated by dark coloration in the inner circles. (B) Genomic regions surrounding the BT_1526/MIPS homolog in representative Bacteroidetes, compiled using the PATRIC 3.6.9 Compare Region Viewer. Protein homology (determined using NCBI-BlastP) to proteins in the BT-like inositol lipid metabolism cluster (left in key) or the Bacteroides vulgatus-like putative alternative inositol metabolism cluster (right in key) is indicated by color. The functions of enzymes in bold were characterized in this study; sequences with predicted redundant functions between both clusters are linked in the key.

alternative pathway among the Bacteroidetes, we searched for homology in 162 representative species of these genera (Bacteroides, Prevotella, Parabacteroides, Porphyromonas,

Sphingobacterium, and Chlorobium spp.) (Table S4). Most strains with a homolog to BT_1522,

BT_1523, or BT_1525, in fact have homologs of all three of these enzymes, with a distribution that does not track phylogeny, supporting the lateral exchange of this full cluster among these hostassociated species (Fig. 6). Roughly three-quarters of species we assessed belonging to the Bacteroides, Prevotella, and Parabacteroides genera have a MIPS/BT_1526 homolog, and most species with a MIPS homolog contain either the BT-like inositol lipid cluster or the putative alternative cluster. One notable exception is Bacteroides fragilis, which does not produce inositol lipids but synthesizes the bioactive glycosphingolipid $\alpha$-galactosylceramide ${ }^{51,52}$. The BT-like inositol lipid gene cluster is roughly two times more common than the alternative cluster among Bacteroides species, while the alternative cluster is about four times more common among the Prevotella species. Homologs to proteins in either cluster were absent or highly infrequent in the genera Porphyromonas, Sphingobacterium, and Chlorobium, with the exceptions of moderate alternative cluster homology in Sphingobacteria, and extensive BT_1525 homology in Chlorobium (Table S4), which may reflect a true phosphatidylglycerophosphatase function. 

attributes of the gut microbiome. been shown to influence the metabolism and immune homeostasis of their hosts ${ }^{14,19,51,53-55}$. Likewise, bacteria are already known to manipulate their host through inositol and inositol lipid metabolic pathways ${ }^{43,56}$, and many bacterial and viral pathogens have also adapted to hijack the host phosphoinositide system ${ }^{57,58}$. Thus, a precedent exists for trans-kingdom manipulation of inositol levels, to either a beneficial or detrimental outcome for the host. As one of the most 
381

382

383

384

385

386

387

388

389

390

391

392

393

394

395

396

397

398

399

400

401

402

403

404

405

406

407

\section{Conclusion}

Inositol lipids have only recently been reported in commensal gut bacteria. In this study, we characterized the gene cluster recently hypothesized to be involved in bacterial inositol lipid synthesis in BT, in the first known study to show a functional role for these genes in the Bacteroidetes. BT synthesizes PI using a mycobacterial-like pathway with a PIP intermediate; previously, the bacterial PI synthesis pathway lacked a PIPh, which we have identified here as BT_1525. We also identified a putative alternative pathway for PI-DHC synthesis common among Prevotella species that lacks a PIP intermediate resembling the eukaryotic Kennedy pathway for phosphatidylethanolamine and phosphatidylcholine synthesis. The majority of Bacteroidetes encode one or the other of these pathways, indicating that inositol lipid production is a fundamental trait in the phylum. Together with the importance of inositol lipids in pathogen-host interactions ${ }^{60}$, their high prevalence in the host-associated Bacteroidetes suggests an unexplored role in host interactions, potentially mediated both directly through provisioning and indirectly via effects on the capsule.

\section{Materials and Methods}

\section{Bacterial strains and culturing conditions}

Unless otherwise stated, all liquid B. thetaiotaomicron VPI-5482 (BT) cultures were grown anaerobically ( $95 \% \mathrm{~N}_{2}$ and $5 \% \mathrm{CO}_{2}$ atmosphere) at $37^{\circ} \mathrm{C}$ in supplemented $\mathrm{BHI}$ media (BHIS; $37 \mathrm{~g} / \mathrm{L}$ brain-heart infusion, $5 \mathrm{~g} / \mathrm{L}$ yeast extract, $1 \mathrm{mg} / \mathrm{L}$ menadione, $1 \mathrm{mg} / \mathrm{L}$ resazurin, $10 \mathrm{mg} / \mathrm{L}$ hemin, $0.5 \mathrm{~g} / \mathrm{L}$ cysteine-HCl). E. coli cultures were grown aerobically at $37^{\circ} \mathrm{C}$ in Luria broth with shaking. Final concentrations of antibiotics and selection agents were as follows: erythromycin $25 \mu \mathrm{g} / \mathrm{mL}$, gentamicin $200 \mu \mathrm{g} / \mathrm{mL}$, streptomycin $100 \mu \mathrm{g} / \mathrm{mL}$, carbenicillin $100 \mu \mathrm{g} / \mathrm{mL}$, 5-fluoro-2'-deoxyuridine $200 \mu \mathrm{g} / \mathrm{mL}$. In select experiments, BT was grown in Bacteroides minimal media (BMM); per liter: $13.6 \mathrm{~g} \mathrm{KH}_{2} \mathrm{PO}_{4}, 0.875 \mathrm{~g} \mathrm{NaCl}, 1.125 \mathrm{~g}\left(\mathrm{NH}_{4}\right)_{2} \mathrm{SO}_{4}, 5 \mathrm{~g}$ glucose, ( $\mathrm{pH}$ to 7.2 with concentrated $\mathrm{NaOH}$ ), $1 \mathrm{~mL}$ hemin ( $500 \mathrm{mg}$ dissolved in $10 \mathrm{~mL}$ of $1 \mathrm{M} \mathrm{NaOH}$ then diluted to final volume of $500 \mathrm{~mL}$ with water), $1 \mathrm{~mL} \mathrm{MgCl}$ (0.1 M in water), $1 \mathrm{~mL} \mathrm{FeSO}{ }_{4} \times 7 \mathrm{H}_{2} \mathrm{O}$ (1 mg per $10 \mathrm{~mL}$ of water), $1 \mathrm{~mL}$ vitamin 

cysteine $\mathrm{HCl}$.

For lipid analysis of non-BT strains: Sphingomonas paucimobilis (ATCC 29837) was grown aerobically at

$41130^{\circ} \mathrm{C}$ in nutrient broth (per L: $5.0 \mathrm{~g}$ peptone, $3.0 \mathrm{~g}$ meat extract; $\mathrm{pH} 7.0$ ). Bacteroides fragilis (DSM 2151),

412 Porphyromonas gingivalis (DSM 20709), Bacteroides uniformis (DSM 6597), Bacteroides vulgatus H5_1 (DSM

413 108228), Bacteroides vulgatus (DSM 1447), Prevotella veroralis (ATCC 33779), and Prevotella copri (DSM

414 18205) were grown anaerobically at $37^{\circ} \mathrm{C}$ in BHIS. Flectobacillus major (DSM 103) was grown at $26^{\circ} \mathrm{C}$ in DSM g yeast extract, $1.0 \mathrm{~g}$ peptone; $\mathrm{pH}$ 5.5). BT_0870 (SPT) knockout is previously described ${ }^{54}$. To create the inducible SPT (iSPT) strain, three TetR described ${ }^{27}$, with the native SPT (BT_0870) sequence reintroduced under the inducible P1TDP promoter. $B T_{-} 1522, B T_{-} 1523, B T_{-} 1525$, and $B T_{-} 1526$ were knocked out using the same process in both the WT and iSPT verified by Sanger sequencing. 
bioRxiv preprint doi: https://doi org/10.1101/2021.04.26.441525; this version posted April 27, 2021. The copyright holder for this preprint (which was not certified by peer review) is the author/funder, who has granted bioRxiv a license to display the preprint in perpetuity. It is made available under aCC-BY-NC 4.0 International license.

437

438

439

440

441

442

443

444

445

446

447

448

449

450

451

452

453

454

455

456

457

458

459

460

461

462

463

464

465

minutes at $4^{\circ} \mathrm{C}$, resuspended in $5-\mathrm{mL}$ cold $0.5 \mathrm{M}$ trichloroacetic acid (TCA), incubated 5 minutes on ice, and pelleted at $3500 \times \mathrm{g}$ for 15 minutes at $4^{\circ} \mathrm{C}$. The pellets were washed twice in $3 \mathrm{~mL} \%$ TCA with $1 \mathrm{mM}$ EDTA, then neutral lipids were extracted twice by vortexing the pellet in $3 \mathrm{~mL} \mathrm{2:1} \mathrm{methanol:chloroform} \mathrm{for} 10$ minutes. The resulting pellets were extracted into $2.25 \mathrm{~mL}$ methanol:chloroform:12 $\mathrm{N} \mathrm{HCl}(80: 40: 1), 0.75 \mathrm{~mL}$ of chloroform and $1.35 \mathrm{~mL}$ of $0.1 \mathrm{~N} \mathrm{HCl}$ added and vortexed. The lower fraction was dried under nitrogen and resuspended in 20:9:1 chloroform:methanol:water for TLC.

\section{Thin layer chromatography of lipids}

Lipid extracts were applied to a silica HPTLC plate with concentration zone (Supelco \#60768), with loading volumes normalized to the $\mathrm{OD}_{600}$ of original cultures. Plates were developed in a 62:25:4 (v/v) chloroform:methanol:ammonium hydroxide system (for standard lipid extractions) or 48:40:7:5

chloroform:methanol:water:ammonium hydroxide (for PIP extractions), then sprayed with primuline (0.1 $\mathrm{mg} / \mathrm{mL}$ in 4:1 $\mathrm{v} / \mathrm{v}$ acetone: $\mathrm{dH}_{2} \mathrm{O}$ ), and imaged under UV transillumination $(365 \mathrm{~nm})$. Lipid standards include 16:0 phosphatidylinositol (Avanti \#850141), 18:1 PI(3)P (Avanti \#850150), ceramide phosphorylethanolamine (Sigma-Aldrich \#C4987), egg yolk phosphatidylethanolamine (Pharmacoepia), d18:1/18:0 ceramide (Cayman \#19556), and d18:0 sphinganine (Avanti \#860498).

\section{Sample Prep For HPLC-MS}

Samples were frozen over liquid nitrogen and lyophilized to dryness. $1 \mathrm{~mL}$ of HPLC grade methanol was added to the dried material and the mixture was sonicated for $3 \mathrm{~min}$ (on/off pulse cycles of 2 second on, 2 seconds off, at power 100\%) using a Qsonica Ultrasonic Processor (Model Q700) with a water bath cup horn adaptor (Model 431C2), with water bath flow to maintain approximately room temperature. Samples were then moved to an end-over-end rotator and extractions proceeded for 12 hours. Samples were then centrifuged at $18000 \mathrm{G}$ for 30 minutes at $4{ }^{\circ} \mathrm{C}$. The supernatant was transferred to a fresh centrifuge tube and solvent was dried with a Thermo Scientific Savant SpeedVac SPD130DLX. The dried material was resuspended in $200 \mu \mathrm{L} \mathrm{HPLC}$-grade methanol, briefly sonicated, and centrifuged as before. The concentrated extract was transferred to HPLC vial with a $300 \mu \mathrm{L}$ glass insert and stored at $4{ }^{\circ} \mathrm{C}$ until further analysis.

$\underline{\text { HPLC-MS instrumentation }}$

LC-MS analysis was performed on a ThermoFisher Scientific Vanquish Horizon UHPLC System coupled with a ThermoFisher Scientific TSQ Quantis Triple Quadrupole mass spectrometer equipped with a HESI ion source. All solvents and reagent for HPLC-MS were purchased as Optima LC-MS grade (Fisher Scientific). 
acetate. Mobile phase B was $99.9 \%$ methanol, and $0.1 \%$ formic acid (v/v). $1 \mu \mathrm{L}$ of extract was injected and separated on a mobile phase gradient with an Agilent Technologies InfinityLab Poroshell 120 EC-C18 column

$470(50 \mathrm{~mm} \times 2.1 \mathrm{~mm}$, particle size $2.7 \mu \mathrm{m}$, part number: $699775-902)$ maintained at $50^{\circ} \mathrm{C}$. A/B gradient started at $47115 \%$ B for 1 min after injection and increased linearly to $100 \%$ B at 22 min and held at $100 \%$ B for 5 min, using a flow rate $0.6 \mathrm{~mL} / \mathrm{min}$. Full Scan Q1 mass spectrometer parameters: spray voltage $2.0 \mathrm{kV}$ for negative mode, ion

473 transfer tube temperature $350^{\circ} \mathrm{C}$, vaporizer temperature $350^{\circ} \mathrm{C}$; sheath, auxiliary, and spare gas 60,15 , and 2 , 474 respectively. Tandem mass spectrum analysis was carried out with Product lon Scan mode with the following additions: collision energy: $30 \mathrm{~V}, \mathrm{CID}$ gas 1.5 mTorr. $4^{\circ} \mathrm{C}$, and the aqueous phase ethanol precipitated (cold absolute EtOH added to final concentration $80 \% \mathrm{v} / \mathrm{v}$ for 
bioRxiv preprint doi: https://doi org/10.1101/2021.04.26.441525; this version posted April 27, 2021. The copyright holder for this preprint (which was not certified by peer review) is the author/funder, who has granted bioRxiv a license to display the preprint in perpetuity. It is made available under aCC-BY-NC 4.0 International license. transform E. coli BL21 (DE3) cells for overexpression. The BT_1526 MIPS protein was expressed by culturing the transformed cells in LB medium supplemented with $35 \mathrm{ug} / \mathrm{ml}$ kanamycin at $37^{\circ} \mathrm{C} 200 \mathrm{rpm}$ shaking, until the cells reached the mid-exponential growth stage $\left(\mathrm{OD}_{600}=0.5\right)$. Protein expression was then induced by the addition of $0.1 \mathrm{mM}$ IPTG for five hours with a reduced temperature of $30^{\circ} \mathrm{C}$ with shaking $200 \mathrm{rpm}$. Cells were harvested by centrifugation $4000 \times \mathrm{g}, 4^{\circ} \mathrm{C}$ and sonicated in $10 \times \mathrm{v} / \mathrm{w}$ HisA buffer $(50 \mathrm{mM}$ Tris- $\mathrm{HCl}, 20 \mathrm{mM}$ $\mathrm{NH} 4 \mathrm{Cl}, 0.2 \mathrm{mM}$ DTT and $30 \mathrm{mM}$ imidazole, $\mathrm{pH} 7.5$ ) to lyse the cells. The lysate was clarified by centrifugation at $35,000 \times \mathrm{g}, 4^{\circ} \mathrm{C}$ and the supernatant was loaded onto a $5 \mathrm{ml} \mathrm{HisTrap} \mathrm{column} \mathrm{(Cytiva)} \mathrm{equilibrated} \mathrm{with} \mathrm{HisA}$ buffer. Unbound proteins were washed off the column with 20 column volumes of HisA prior to elution of the tagged BT_1526 with HisB buffer (20 mM NH $4 \mathrm{Cl}, 0.2 \mathrm{mM}$ DTT and $500 \mathrm{mM}$ imidazole, pH 7.5). The protein was then subjected to size-exclusion chromatography for polishing and buffer exchange. A Superdex S200 column was equilibrated with $\mathrm{GF}$ buffer ( $50 \mathrm{mM}$ Tris- $\mathrm{HCl}$ and $150 \mathrm{mM} \mathrm{NaCl}$ ) and sample added for isocratic elution over 1.2 column volumes. Fractions from size-exclusion chromatography were analyzed by $15 \%$ SDS-PAGE and fractions containing the pure BT_1526 protein were pooled and used in subsequent experiments. The yield of recombinant BT_1526 was typically >20mg per litre of E. coli culture.

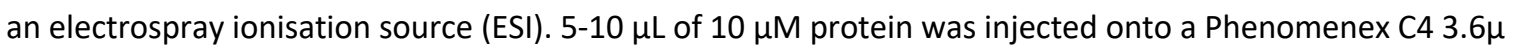
column. The conditions for the qTOF are as follows: source temperature $120^{\circ} \mathrm{C}$, back pressure $2 \mathrm{mbar}$, and sampling cone voltage $54 \mathrm{~V}$. The protein was eluted with a 12 minute gradient, starting at $5 \%$ acetonitrile with

$5170.1 \%$ formic acid to $95 \%$ acetonitrile. The resulting spectra were processed and the charge state distributions deconvoluted using MassLynx V4.1 software.

521 (see Fig. 3A). The assay was as follows: $1 \mu \mathrm{M}$ enzyme, 0-50 mM D-glucose-6-phosphate, $0.8 \mathrm{mM}$ NAD+ for $1 \mathrm{hr}$ 
bioRxiv preprint doi: https://doi org/10.1101/2021.04.26.441525; this version posted April 27, 2021. The copyright holder for this preprint (which was not certified by peer review) is the author/funder, who has granted bioRxiv a license to display the preprint in perpetuity. It is made available under aCC-BY-NC 4.0 International license.

524 at room temperature, then the absorbance was measured on BioTek Synergy HT plate reader at $820 \mathrm{~nm}$.

525 Values were determined with reference to inorganic phosphate standards.

526

527

528

529

530

531

532

533

534

535

536

537

538

539

540

541

542

543

544

545

546

547

548

549

550

551

552

Crystallization of BT 1526

MIPS was initially screened using commercial kits (Molecular Dimensions and Hampton Research). The protein concentration was $11.4 \mathrm{mg} / \mathrm{ml}$. The drops, composed of $0.1 \mathrm{ul}$ or $0.2 \mathrm{ul}$ of protein solution plus 0.1 of reservoir solution, were set up using a Mosquito crystallization robot (SPT Labtech) using the sitting drop vapor diffusion method. The plates were incubated at $20^{\circ} \mathrm{C}$ and the initial hits were suitable for diffraction experiments. The condition yielding crystals that were subjected to X-ray diffraction was PACT F6 (Molecular Dimensions, 200 mM Sodium formate, 100 mM Bis Tris Propane pH 6.5, and 20 \% (w/v) PEG 3350). The sample was cryoprotected with the addition of $20 \%$ PEG 400 to the reservoir solution.

Data collection, structure solution, model building, refinement and validation of BT 1526

Diffraction data were collected at the synchrotron beamline 104 of Diamond light source (Didcot, UK)

at a temperature of $100 \mathrm{~K}$. The data set was integrated with XIA2 ${ }^{63}$ using DIALS ${ }^{64}$ and scaled with Aimless (52).

The space group was confirmed with Pointless ${ }^{65}$. The phase problem was solved by molecular replacement with Phaser ${ }^{66}$ using PDB file 3QVT as search model. The model was refined with refmac ${ }^{67}$ and manual model building with СООт $^{68}$. The model was validated using Coot and Molprobity ${ }^{69}$. Other software used were from CCP4 cloud and the CCP4 suite ${ }^{70}$. Figures were made with ChimeraX ${ }^{71}$.

\section{Electron microscopy}

Imaging was performed by the Electron Microscopy Core at the Max Planck Institute for

Developmental Biology in Tübingen, Germany. For scanning electron microscopy (SEM), cells were fixed in $2.5 \%$ glutaraldehyde/4\% formaldehyde in PBS for 2 hours at room temperature and mounted on poly-L-lysinecoated cover slips. Cells were post-fixed with $1 \%$ osmium tetroxide for 45 minutes on ice. Subsequently, samples were dehydrated in a graded ethanol series followed by critical point drying (Polaron) with $\mathrm{CO}_{2}$. Finally, the cells were sputter-coated with a $3 \mathrm{~nm}$ thick layer of platinum (CCU-010, Safematic) and examined with a field emission scanning electron microscope (Regulus 8230, Hitachi High Technologies) at an accelerating voltage of $3 \mathrm{kV}$.

$\underline{\text { RNA-seq of BT at varied levels of SPT induction }}$

Overnight cultures were used to inoculate (in duplicate) BMM media 1:2500 uninduced, or at one of five varied anhydrotetracycline (aTC) concentrations $(0,0.2,1.0,5.0,100 \mathrm{ng} / \mathrm{mL})$, and incubated at $37^{\circ} \mathrm{C}$ for 14 
hours to an OD600 of 0.10-0.17. Cultures were spun at $3500 \mathrm{xg}$ for $15 \mathrm{~min}$ and RNA was extracted from the

554 bacterial pellet with QIAzol lysis reagent and the miRNeasy Mini Kit (Qiagen). rRNA was removed with the Bacterial RiboMinus Transcriptome Isolation Kit (Invitrogen) and the library prepared with the TruSeq Stranded Total RNA Library Kit (Illumina); libraries were pooled nine per lane and sequenced by HiSeq3000 (Illumina). Quality assessment of reads was performed using FastQC pre- and post-quality filtering with bbduk

558 (quality cutoff $=20)^{72}$. Reads were aligned to the Ensembl B. thetaiotaomicron VPI-5482 genome with bowtie2 and assigned using htseq-count (alignment quality cutoff $=10)^{73-75}$. Differential expression analysis was performed with EdgeR and limma ${ }^{76,77}$ : reads assigned to rRNA genes, "ambiguous," or "no feature" were removed, lowly expressed genes were filtered, and gene expression distributions were normalized (method Trimmed Means of M values, "TMM"). Count data from BMM samples, which were in duplicate, were further normalized by Bayes moderated variance before calculation of differential expression (adjusted p-value via Benjamini-Hochberg method). Annotations were assigned from the JGI IMG database. Heatmaps were generated with pheatmap using normalized log2 expression values, scaled by row with Euclidean clustering. Phylogenies of homology to BT inositol lipid metabolic enzymes in diverse bacteria inositol lipid metabolism enzymes BT_1522, BT_1523, BT_1525, and BT_1526 was identified using NCBI Blast-P

${ }^{78}$ to the indicated species. For the larger phylogeny of Bacteroidetes and related genera (Fig. 5), all representative species for Bacteroides, Prevotella, Parabacteroides, Porphyromonas, Flavobacterium, Sphingobacterium, and Chlorobium genera with nomenclature recognized in the LPSN ${ }^{79}$ were tested for homology to BT inositol metabolism enzymes BT_1522, BT_1523, BT_1525, BT_1526, and BT_4744. For phylogenetic comparison in both trees, 71 single copy genes present in all genomes (HMM profile Bacteria_71) were identified and concatened using Anvi'o ${ }^{80}$, with alignment using MUSCLE ${ }^{81}$. RAxML ${ }^{82}$ was used to generate a maximum likelihood tree (Protcat substitution model, Dayhoff matrix, Hill-climbing algorithm, 50 bootstrap iterations). Strain accession numbers and Blast-P results are in Table S4.

\section{7}


bioRxiv preprint doi: https://doi.org/10.1101/2021.04 26.441525; this version posted April 27,2021 . The copyright holder for this preprint

(which was not certified by peer review) is the author/funder, who has granted bioRxiv a license to display the preprint in perpetuity. It is made available under aCC-BY-NC 4.0 International license.

582 thetaiotaomicron. We would like to thank Diamond Light Source (Oxfordshire, UK) for beamtime

583 (proposal $m \times 24948$ ) and staff of beamline I04. Both DJC and JMW would like to acknowledge the

584 funding provided by the Biotechnology and Biological Sciences Research Council (BBSRC, grants

585

BB/V001620/1 and BB/V00168X/1).

586

587

\section{Data Availability}

588

The BT_1526 MIPS structure analyzed during the current study is available in the Protein

589 Data Bank repository, PDB 7NWR. Transcriptomic reads, mass spectrometry files, and all unique

590 strains generated in this study are available from the corresponding author upon request. All

591 remaining data generated during this study are included in this published article and its

592 supplementary information files.

593

594 
5961. Nakase, M. et al. Mannosylinositol phosphorylceramide is a major sphingolipid component and is required for 597 proper localization of plasma-membrane proteins in Schizosaccharomyces pombe. J. Cell Sci. 123, 1578-1587

598 (2010)

5992. Megyeri, M., Riezman, H., Schuldiner, M. \& Futerman, A. H. Making sense of the yeast sphingolipid pathway. J.

600 Mol. Biol. 428, 4765-4775 (2016).

6013. Dickson, E. J. \& Hille, B. Understanding phosphoinositides: rare, dynamic, and essential membrane

602 phospholipids. Biochem. J 476, 1-23 (2019).

6034. Phan, T. K. et al. Phosphoinositides: multipurpose cellular lipids with emerging roles in cell death. Cell Death

604 Differ. 26, 781-793 (2019).

6055. Haites, R. E., Morita, Y. S., McConville, M. J. \& Billman-Jacobe, H. Function of phosphatidylinositol in

606 mycobacteria. J. Biol. Chem. 280, 10981-10987 (2005).

6076. Yagüe, G., Segovia, M. \& Valero-Guillén, P. L. Phospholipid composition of several clinically relevant

608 Corynebacterium species as determined by mass spectrometry: an unusual fatty acyl moiety is present in

609 inositol-containing phospholipids of Corynebacterium urealyticum. Microbiology 149, 1675-1685 (2003).

6107. Masayama, A. et al. Streptomyces phospholipase D mutants with altered substrate specificity capable of

611 phosphatidylinositol synthesis. Chembiochem 9, 974-981 (2008).

6128. Belisle, J. T., Brandt, M. E., Radolf, J. D. \& Norgard, M. V. Fatty acids of Treponema pallidum and Borrelia

613 burgdorferi lipoproteins. J. Bacteriol. 176, 2151-2157 (1994).

6149. Nigou, J., Gilleron, M. \& Puzo, G. Lipoarabinomannans: from structure to biosynthesis. Biochimie 85, 153-166 615 (2003)

61610. Olson, D. K., Fröhlich, F., Farese, R. V., Jr \& Walther, T. C. Taming the sphinx: Mechanisms of cellular

617 sphingolipid homeostasis. Biochim. Biophys. Acta 1861, 784-792 (2016).

61811. Michell, R. H. Inositol lipids: from an archaeal origin to phosphatidylinositol 3,5-bisphosphate faults in human 619 disease. FEBS J. 280, 6281-6294 (2013).

62012. Hannun, Y. A. \& Obeid, L. M. Sphingolipids and their metabolism in physiology and disease. Nat. Rev. Mol. Cell Biol. 19, 175-191 (2018). 
bioRxiv preprint doi: https://doi.org/10.1101/2021.04.26.441525; this version posted April 27 2021. The copyright holder for this preprint (which was not certified by peer review) is the author/funder, who has granted bioRxiv a license to display the preprint in perpetuity. It is made available under aCC-BY-NC 4.0 International license.

62213. Megson, Z. A. et al. Inositol-phosphodihydroceramides in the periodontal pathogen Tannerella forsythia:

623 Structural analysis and incorporation of exogenous myo-inositol. Biochim. Biophys. Acta 1851, 1417-1427

624 (2015).

62514. Brown, E. M. et al. Bacteroides-Derived Sphingolipids Are Critical for Maintaining Intestinal Homeostasis and

626 Symbiosis. Cell Host Microbe 25, 668-680.e7 (2019).

62715. Naka, T. et al. Structural analysis of sphingophospholipids derived from Sphingobacterium spiritivorum, the

628 type species of genus Sphingobacterium. Biochim. Biophys. Acta 1635, 83-92 (2003).

62916. Lorenzen, W., Bozhüyük, K. A. J., Cortina, N. S. \& Bode, H. B. A comprehensive insight into the lipid composition 630 of Myxococcus xanthus by UPLC-ESI-MS. J. Lipid Res. 55, 2620-2633 (2014).

63117. Morii, H., Ogawa, M., Fukuda, K., Taniguchi, H. \& Koga, Y. A revised biosynthetic pathway for

632 phosphatidylinositol in Mycobacteria. J. Biochem. 148, 593-602 (2010).

63318. Belcher Dufrisne, M. et al. Structural and Functional Characterization of Phosphatidylinositol-Phosphate

634 Biosynthesis in Mycobacteria. J. Mol. Biol. 432, 5137-5151 (2020).

63519. Harrison, P. J., Dunn, T. M. \& Campopiano, D. J. Sphingolipid biosynthesis in man and microbes. Nat. Prod. Rep.

636 (2018) doi:10.1039/c8np00019k.

63720. Koropatkin, N. M., Martens, E. C., Gordon, J. I. \& Smith, T. J. Starch catabolism by a prominent human gut

638 symbiont is directed by the recognition of amylose helices. Structure 16, 1105-1115 (2008).

63921. Xu, J. et al. A genomic view of the human-Bacteroides thetaiotaomicron symbiosis. Science 299, 2074-2076

640 (2003).

64122. Clarke, O. B. et al. Structural basis for phosphatidylinositol-phosphate biosynthesis. Nat. Commun. 6, 8505 642 (2015).

64323. Ryan, D., Jenniches, L., Reichardt, S., Barquist, L. \& Westermann, A. J. A high-resolution transcriptome map

644 identifies small RNA regulation of metabolism in the gut microbe Bacteroides thetaiotaomicron. Nat. Commun.

$64511,593(2020)$.

64624. Kolly, G. S. et al. GtrA Protein Rv3789 Is Required for Arabinosylation of Arabinogalactan in Mycobacterium

647 tuberculosis. J. Bacteriol. 197, 3686-3697 (2015).

64825. Fukao, M. et al. Plasmid-encoded glycosyltransferase operon is responsible for exopolysaccharide production,

649 cell aggregation, and bile resistance in a probiotic strain, Lactobacillus brevis KB290. J. Biosci. Bioeng. 128, 391-

650397 (2019). 
bioRxiv preprint doi: https://doi.org/10.1101/2021.04.26.441525; this version posted April 27 2021. The copyright holder for this preprint (which was not certified by peer review) is the author/funder, who has granted bioRxiv a license to display the preprint in perpetuity. It is made available under aCC-BY-NC 4.0 International license.

65126. Mayer, M. J., D’Amato, A., Colquhoun, I. J., Le Gall, G. \& Narbad, A. Identification of Genes Required for Glucan

652 Exopolysaccharide Production in Lactobacillus johnsonii Suggests a Novel Biosynthesis Mechanism. Appl.

653 Environ. Microbiol. 86, (2020).

65427. Lim, B., Zimmermann, M., Barry, N. A. \& Goodman, A. L. Engineered Regulatory Systems Modulate Gene

655 Expression of Human Commensals in the Gut. Cell 169, 547-558.e15 (2017).

65628. Barnett, J. E., Brice, R. E. \& Corina, D. L. A colorimetric determination of inositol monophosphates as an assay

657 for D-glucose 6-phosphate-1L-myoinositol 1-phosphate cyclase. Biochem. J 119, 183-186 (1970).

65829. Chatterjee, A., Majee, M., Ghosh, S. \& Majumder, A. L. sll1722, an unassigned open reading frame of

659 Synechocystis PCC 6803, codes for L-myo-inositol 1-phosphate synthase. Planta 218, 989-998 (2004).

66080. Donahue, T. F. \& Henry, S. A. myo-Inositol-1-phosphate synthase. Characteristics of the enzyme and

661 identification of its structural gene in yeast. J. Biol. Chem. 256, 7077-7085 (1981).

66231. Chen, L., Zhou, C., Yang, H. \& Roberts, M. F. Inositol-1-phosphate synthase from Archaeoglobus fulgidus is a

663 class II aldolase. Biochemistry 39, 12415-12423 (2000).

66432. Donahue, J. L. et al. The Arabidopsis thaliana Myo-inositol 1-phosphate synthase1 gene is required for Myo-

665 inositol synthesis and suppression of cell death. Plant Cell 22, 888-903 (2010).

66633. Norman, R. A. et al. Crystal structure of inositol 1-phosphate synthase from Mycobacterium tuberculosis, a key

667 enzyme in phosphatidylinositol synthesis. Structure 10, 393-402 (2002).

66834. Jin, X. \& Geiger, J. H. Structures of NAD+- and NADH-bound 1-I-myo-inositol 1-phosphate synthase. Acta

669 Crystallogr. D Biol. Crystallogr. 59, 1154-1164 (2003).

67085. Stieglitz, K. A., Yang, H., Roberts, M. F. \& Stec, B. Reaching for mechanistic consensus across life kingdoms:

671 structure and insights into catalysis of the myo-inositol-1-phosphate synthase (mIPS) from Archaeoglobus

672 fulgidus. Biochemistry 44, 213-224 (2005).

67336. Kudo, F., Tsunoda, T., Yamaguchi, K., Miyanaga, A. \& Eguchi, T. Stereochemistry in the Reaction of the myo-

674 Inositol Phosphate Synthase Ortholog Ari2 during Aristeromycin Biosynthesis. Biochemistry 58, 5112-5116

675 (2019).

67637. Chhetri, D. R., Adhikari, J. \& Mukherjee, A. K. NAD+ mediated differential thermotolerance between

677 chloroplastic and cytosolic L-myo-inositol-1-phosphate synthase from Diplopterygium glaucum (Thunb.) Nakai.

678 Prep. Biochem. Biotechnol. 36, 307-319 (2006). 
bioRxiv preprint doi: https://doi.org/10.1101/2021.04.26.441525; this version posted April 27 2021. The copyright holder for this preprint (which was not certified by peer review) is the author/funder, who has granted bioRxiv a license to display the preprint in perpetuity. It is made available under aCC-BY-NC 4.0 International license.

67938. Gronnier, J., Germain, V., Gouguet, P., Cacas, J.-L. \& Mongrand, S. GIPC: Glycosyl Inositol Phospho Ceramides,

680 the major sphingolipids on earth. Plant Signal. Behav. 11, e1152438 (2016).

68139. Cerantola, V. et al. Aureobasidin A arrests growth of yeast cells through both ceramide intoxication and

682 deprivation of essential inositolphosphorylceramides. Mol. Microbiol. 71, 1523-1537 (2009).

68340. Porter, N. T., Canales, P., Peterson, D. A. \& Martens, E. C. A Subset of Polysaccharide Capsules in the Human

684 Symbiont Bacteroides thetaiotaomicron Promote Increased Competitive Fitness in the Mouse Gut. Cell Host

685 Microbe 22, 494-506.e8 (2017).

68641. Porter, N. T. et al. Phase-variable capsular polysaccharides and lipoproteins modify bacteriophage susceptibility

687 in Bacteroides thetaiotaomicron. Nature Microbiology (2020) doi:10.1038/s41564-020-0746-5.

68842. Stankeviciute, G., Guan, Z., Goldfine, H. \& Klein, E. A. Caulobacter crescentus Adapts to Phosphate Starvation

689 by Synthesizing Anionic Glycoglycerolipids and a Novel Glycosphingolipid. MBio 10, (2019).

69043. Stentz, R. et al. A bacterial homolog of a eukaryotic inositol phosphate signaling enzyme mediates cross-

691 kingdom dialog in the mammalian gut. Cell Rep. 6, 646-656 (2014).

69244. Brito, J. A., Borges, N., Vonrhein, C., Santos, H. \& Archer, M. Crystal structure of Archaeoglobus fulgidus

693 CTP:inositol-1-phosphate cytidylyltransferase, a key enzyme for di-myo-inositol-phosphate synthesis in

694 (hyper)thermophiles. J. Bacteriol. 193, 2177-2185 (2011).

69545. Huang, H. et al. Panoramic view of a superfamily of phosphatases through substrate profiling. Proc. Natl. Acad.

696 Sci. U. S. A. 112, E1974-83 (2015).

69746. Levine, T. P., Wiggins, C. A. \& Munro, S. Inositol phosphorylceramide synthase is located in the Golgi apparatus

698 of Saccharomyces cerevisiae. Mol. Biol. Cell 11, 2267-2281 (2000).

69947. Blunsom, N. J. \& Cockcroft, S. Phosphatidylinositol synthesis at the endoplasmic reticulum. Biochim. Biophys.

700 Acta Mol. Cell Biol. Lipids 1865, 158471 (2020).

70148. Kennedy, E. P. \& Weiss, S. B. The function of cytidine coenzymes in the biosynthesis of phospholipides. J. Biol.

702 Chem. 222, 193-214 (1956).

70349. Farine, L., Niemann, M., Schneider, A. \& Bütikofer, P. Phosphatidylethanolamine and phosphatidylcholine

704 biosynthesis by the Kennedy pathway occurs at different sites in Trypanosoma brucei. Sci. Rep. 5, 16787 (2015).

70550. Olsen, I. \& Nichols, F. C. Are Sphingolipids and Serine Dipeptide Lipids Underestimated Virulence Factors of

706 Porphyromonas gingivalis? Infect. Immun. 86, (2018). 
bioRxiv preprint doi: https://doi.org/10.1101/2021.04.26.441525; this version posted April 27 2021. The copyright holder for this preprint (which was not certified by peer review) is the author/funder, who has granted bioRxiv a license to display the preprint in perpetuity. It is made available under aCC-BY-NC 4.0 International license.

70751. An, D. et al. Sphingolipids from a symbiotic microbe regulate homeostasis of host intestinal natural killer T cells.

708 Cell 156, 123-133 (2014).

70952. Wieland Brown, L. C. et al. Production of $\alpha$-galactosylceramide by a prominent member of the human gut 710 microbiota. PLoS Biol. 11, e1001610 (2013).

71153. Heaver, S. L., Johnson, E. L. \& Ley, R. E. Sphingolipids in host-microbial interactions. Curr. Opin. Microbiol. 43, 712 92-99 (2018).

71354. Johnson, E. L. et al. Sphingolipids produced by gut bacteria enter host metabolic pathways impacting ceramide 714 levels. Nat. Commun. 11, 2471 (2020).

71555. Rocha, F. G. et al. Porphyromonas gingivalis Sphingolipid Synthesis Limits the Host Inflammatory Response. J. 716 Dent. Res. 22034520908784 (2020) doi:10.1177/0022034520908784.

71756. Wu, S.-E. et al. Microbiota-derived metabolite promotes HDAC3 activity in the gut. Nature (2020)

718 doi:10.1038/s41586-020-2604-2.

71957. Mücksch, F. et al. Quantification of phosphoinositides reveals strong enrichment of PIP2 in HIV-1 compared to 720 producer cell membranes. Sci. Rep. 9, 17661 (2019).

72158. Ledvina, H. E. et al. A Phosphatidylinositol 3-Kinase Effector Alters Phagosomal Maturation to Promote

722 Intracellular Growth of Francisella. Cell Host Microbe 24, 285-295.e8 (2018).

72359. Kraal, L., Abubucker, S., Kota, K., Fischbach, M. A. \& Mitreva, M. The prevalence of species and strains in the 724 human microbiome: a resource for experimental efforts. PLoS One 9, e97279 (2014).

72560. Grāve, K., Bennett, M. D. \& Högbom, M. Structure of Mycobacterium tuberculosis phosphatidylinositol

726 phosphate synthase reveals mechanism of substrate binding and metal catalysis. Commun Biol 2, 175 (2019).

72761. Folch, J., Lees, M. \& Sloane Stanley, G. H. A simple method for the isolation and purification of total lipides

728 from animal tissues. J. Biol. Chem. 226, 497-509 (1957).

72962. Bui, H. H. et al. Direct analysis of $\mathrm{PI}(3,4,5) \mathrm{P} 3$ using liquid chromatography electrospray ionization tandem mass 730 spectrometry. Anal. Biochem. 547, 66-76 (2018).

73163. Winter, G. xia2: an expert system for macromolecular crystallography data reduction. J. Appl. Crystallogr. 43, $732 \quad 186-190$ (2009).

73364. Winter, G. et al. DIALS: implementation and evaluation of a new integration package. Acta Crystallogr D Struct Biol 74, 85-97 (2018). 
73565. Evans, P. R. An introduction to data reduction: space-group determination, scaling and intensity statistics. Acta

736 Crystallogr. D Biol. Crystallogr. 67, 282-292 (2011).

73766. McCoy, A. J. et al. Phaser crystallographic software. J. Appl. Crystallogr. 40, 658-674 (2007).

73867. Murshudov, G. N. et al. REFMAC5 for the refinement of macromolecular crystal structures. Acta Crystallogr. D

739 Biol. Crystallogr. 67, 355-367 (2011).

74068. Emsley, P., Lohkamp, B., Scott, W. G. \& Cowtan, K. Features and development of Coot. Acta Crystallogr. D Biol.

741 Crystallogr. 66, 486-501 (2010).

74269. Williams, C. J. et al. MolProbity: More and better reference data for improved all-atom structure validation.

743 Protein Sci. 27, 293-315 (2018).

74470. Krissinel, E., Uski, V., Lebedev, A., Winn, M. \& Ballard, C. Distributed computing for macromolecular

745 crystallography. Acta Crystallogr D Struct Biol 74, 143-151 (2018).

74671. Pettersen, E. F. et al. UCSF ChimeraX: Structure visualization for researchers, educators, and developers.

747 Protein Sci. 30, 70-82 (2021).

74872. Andrews, S. et al. FastQC. (2012).

74973. Cunningham, F. et al. Ensembl 2019. Nucleic Acids Res. 47, D745-D751 (2019).

75074. Langmead, B. \& Salzberg, S. L. Fast gapped-read alignment with Bowtie 2. Nat. Methods 9, 357-359 (2012).

75175. Anders, S., Pyl, P. T. \& Huber, W. HTSeq--a Python framework to work with high-throughput sequencing data.

752 Bioinformatics 31, 166-169 (2015).

75376. Robinson, M. D., McCarthy, D. J. \& Smyth, G. K. edgeR: a Bioconductor package for differential expression

754 analysis of digital gene expression data. Bioinformatics 26, 139-140 (2010).

75577. Ritchie, M. E. et al. limma powers differential expression analyses for RNA-sequencing and microarray studies.

$756 \quad$ Nucleic Acids Res. 43, e47 (2015).

75778. Camacho, C. et al. BLAST+: architecture and applications. BMC Bioinformatics 10, 421 (2009).

75879. Parte, A. C. LPSN - List of Prokaryotic names with Standing in Nomenclature (bacterio.net), 20 years on. Int. J.

759 Syst. Evol. Microbiol. 68, 1825-1829 (2018).

76080. Murat Eren, A. et al. Anvi'o: an advanced analysis and visualization platform for 'omics data. PeerJ 3, e1319

761 (2015).

76281. Edgar, R. C. MUSCLE: multiple sequence alignment with high accuracy and high throughput. Nucleic Acids Res.

763 32, 1792-1797 (2004). 
bioRxiv preprint doi: https://doi.org/10.1101/2021.04.26.441525; this version posted April 27, 2021. The copyright holder for this preprint (which was not certified by peer review) is the author/funder, who has granted bioRxiv a license to display the preprint in perpetuity. It is made available under aCC-BY-NC 4.0 International license.

76482. Stamatakis, A. RAxML version 8: a tool for phylogenetic analysis and post-analysis of large phylogenies.

765

Bioinformatics 30, 1312-1313 (2014).

766 


\section{Supplementary Figures}
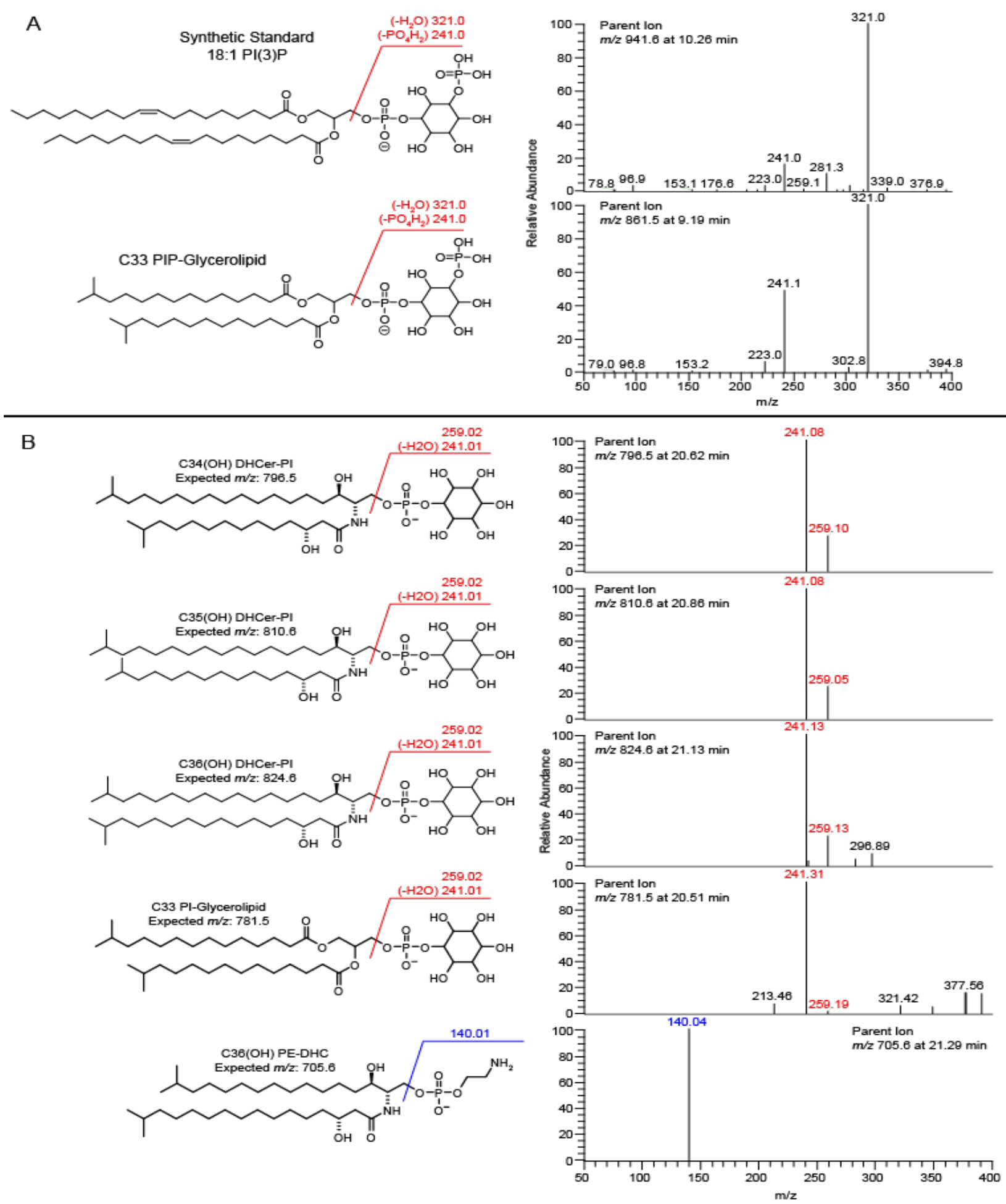

\section{Supplementary Figure 1. Lipid structures and fragmentation patterns of BT inositol and}

ethanolamine lipids (A) Comparison of LC-MS/MS fragmentation patterns of BT-derived PIP with the synthetic standard, 18:1 PI(3)P. (B) LC-MS/MS fragmentation patterns of lipid structures present in iSPT BT at $100 \mathrm{ng} / \mathrm{mL}$ aTC induction, including PI-DHC lipids (C34(OH)DHCer-PI, C35(OH)DHCer-PI, $\mathrm{C} 36(\mathrm{OH}) \mathrm{DHCer}-\mathrm{PI}), \mathrm{C} 33 \mathrm{PI}$-glycerolipid, and C36(OH) PE-DHC. Loss of the phosphoinositol head group is indicated at mass 259. Fragments characteristic for lipids with phosphoinositol-based headgroups are in red; those for phosphoethanolamine-based headgroups are in blue. 
bioRxiv preprint doi: https://doi.org/10.1101/2021.04.26.441525; this version posted April 27, 2021. The copyright holder for this preprint (which was not certified by peer review) is the author/funder, who has granted bioRxiv a license to display the preprint in perpetuity. It is made available under aCC-BY-NC 4.0 International license.

A Novosphingobium acidiphilum
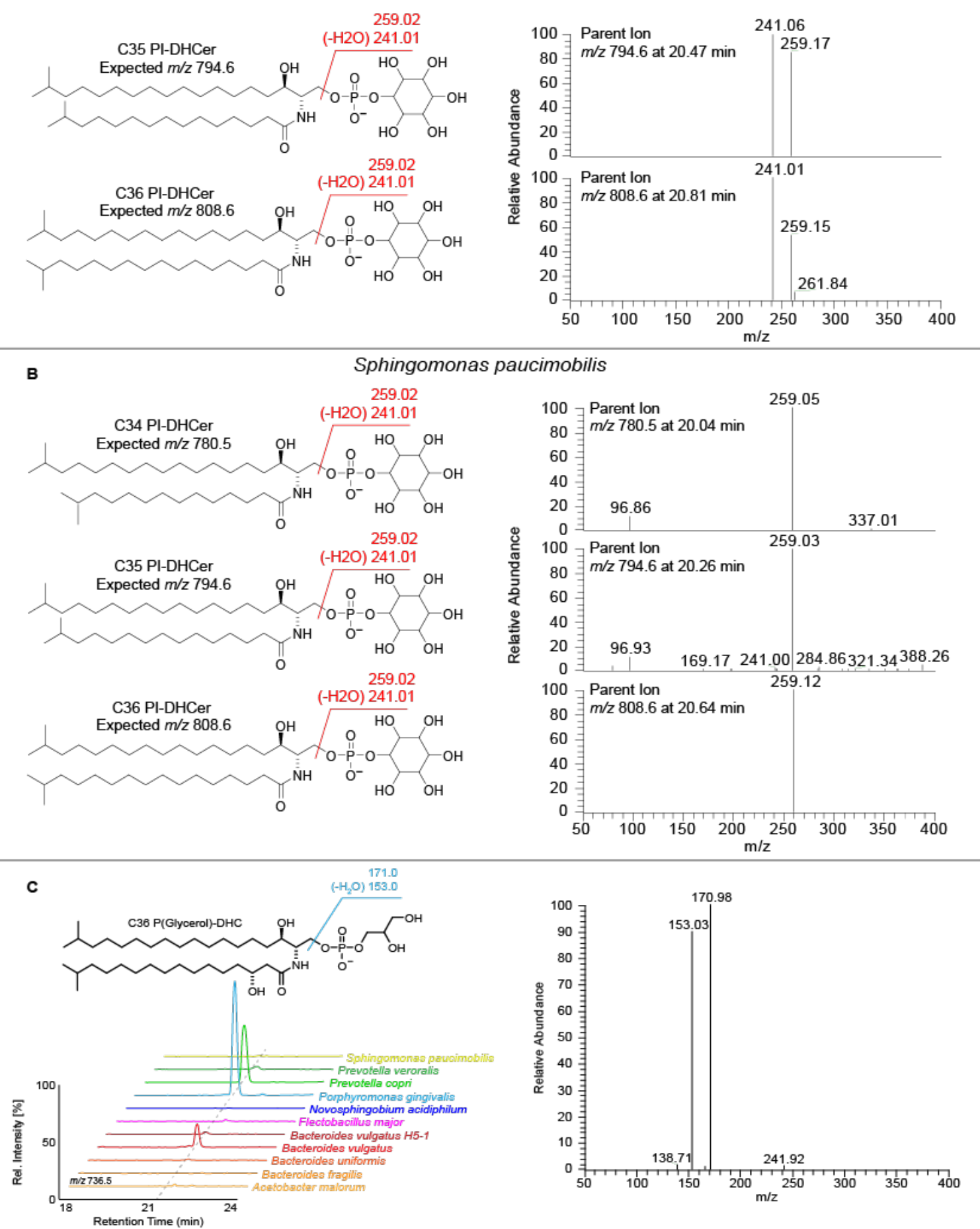

Supplementary Figure 2. Inositol-like lipid structures in diverse sphingolipid-producing species (A) LC-MS/MS fragmentation patterns of lipids extracted from Novosphingobium acidiphilum consistent with the synthesis of C35 and C36 PI-DHC. (B) LC-MS/MS fragmentation pattern of lipids extracted from Sphingomonas paucimobilis, demonstrating the presence of a headgroup with the same mass as inositol phosphate (259) but lacking the characteristic fragment of this group (241). (C) LC-MS/MS spectra and fragmentation pattern of a C36 P(Glycerol)-DHC structure present in Prevotella copri, Porphyromonas gingivalis, and Bacteroides vulgatus. 
bioRxiv preprint doi: https://doi.org/10.1101/2021.04 26.441525; this version posted April 27 2021. The copyright holder for this preprint (which was not certified by peer review) is the author/funder, who has granted bioRxiv a license to display the preprint in perpetuity. It is made available under aCC-BY-NC 4.0 International license.
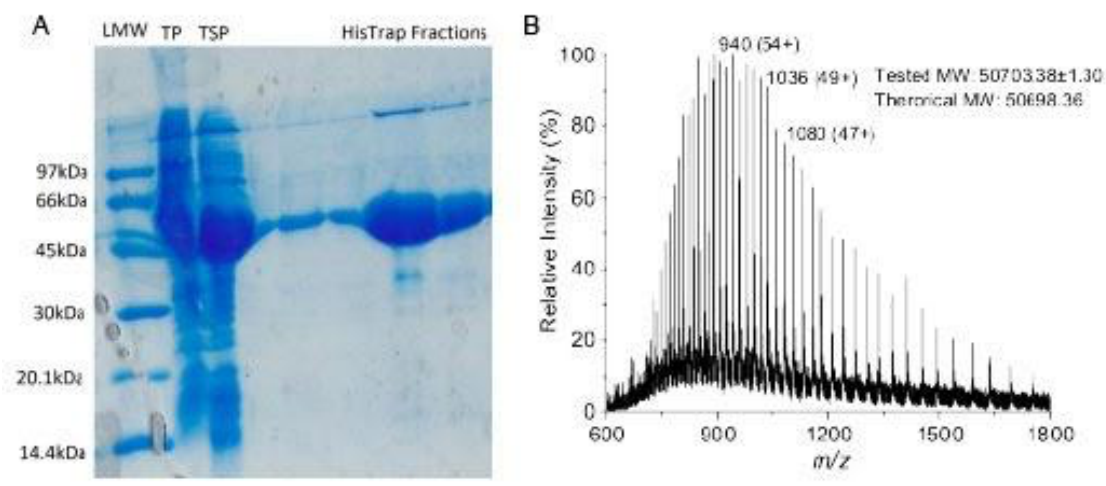

C

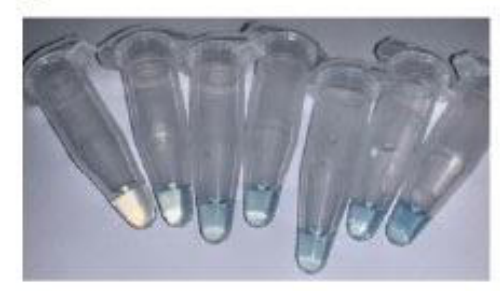

Supplementary Figure 3. Purification of BT_1526 (A) Expression and purification of recombinant BT_1526 MIPS purified from E. coli. The SDS-PAGE analysis shows the purity of the samples isolated by immobilised metal affinity chromatography (IMAC). The band between the 66k and $45 \mathrm{kDa}$ corresponds to BT_1526 MIPS. (B) Electrospray ionisation mass spectrometry (ESI-MS) analysis of the purified BT_1526 MIPS. Positive mode ion envelope with charge states annotated on particular masses. The predicted molecular weight matches well with the theoretical mass without the initial Met residue. (C) Typical colour observed with the molybdenum blue assay of MIPS activity at $820 \mathrm{~nm}$. 
bioRxiv preprint doi: https://doi.org/10.1101/2021.04 26.441525 t this version posted April 27 2021. The copyright holder for this preprint (which was not certified by peer review) is the author/funder, who has granted bioRxiv a license to display the preprint in perpetuity. It is made available under aCC-BY-NC 4.0 International license.
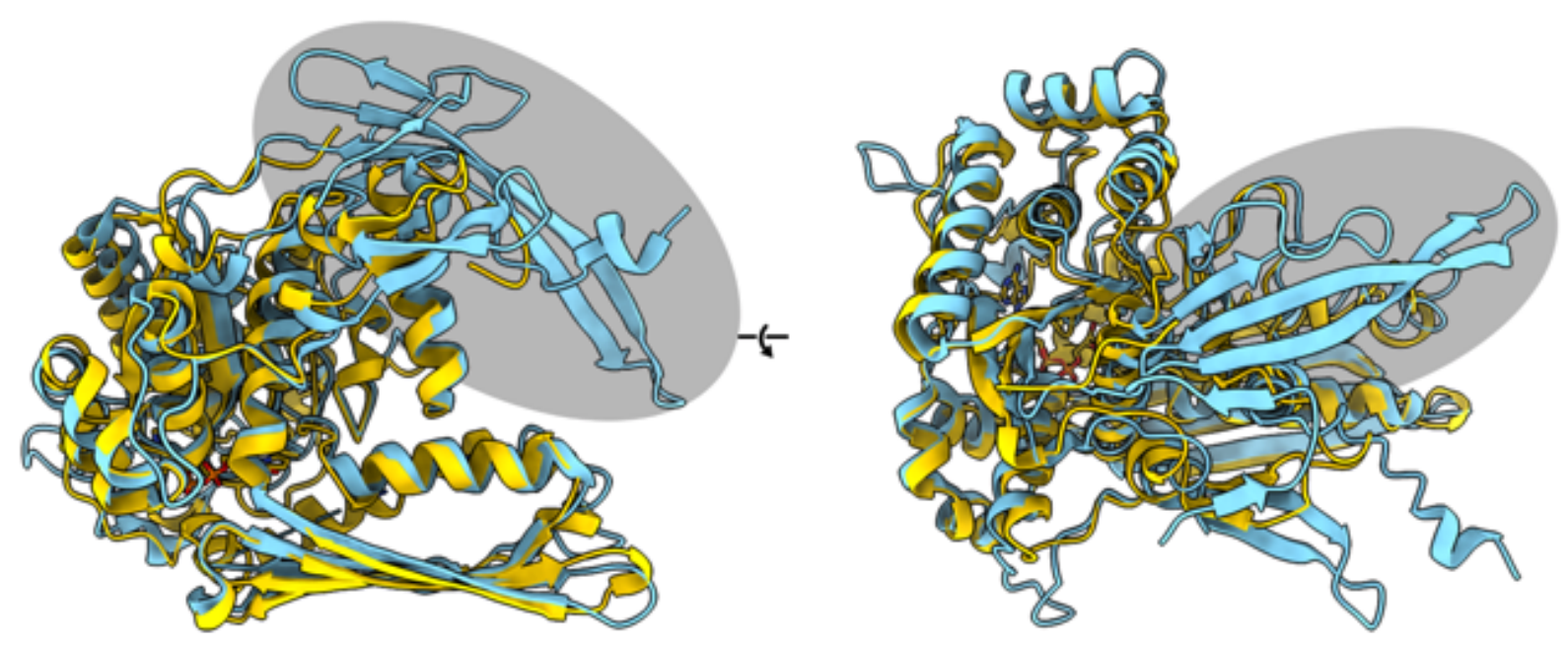

Supplementary Figure 4. Structural comparison of prokaryotic and eukaryotic MIPS proteins. Secondary structure alignment of MIPS BT_1526 (in yellow) and Saccharomyces cerevisiae MIPS (PDBID: 1P1i) (in cyan). The N-terminal extension present in eukaryotic MIPS structures is highlighted with a grey oval. 
bioRxiv preprint doi: https://doi.org/10.1101/2021.04 26.441525; this version posted April 27 2021. The copyright holder for this preprint (which was not certified by peer review) is the author/funder, who has granted bioRxiv a license to display the preprint in perpetuity. It is made available under aCC-BY-NC 4.0 International license.
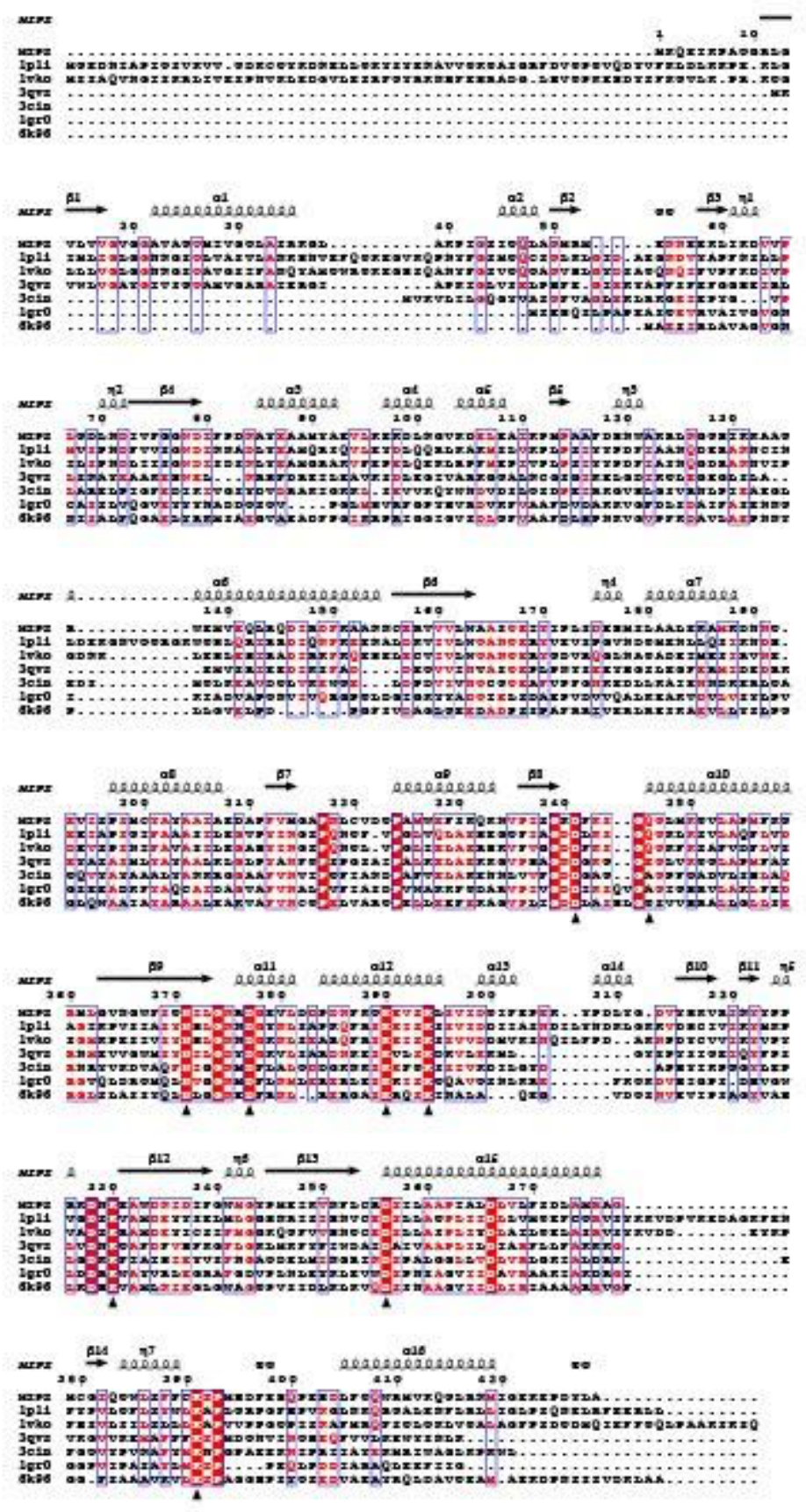

Supplementary Figure 5. MIPS structure and sequence comparison with active site residues. The sequences are: MIPS (BT_1526), 1p1i (Saccharomyces cerevisiae), 1vko (Caenorhabditis elegans), 3qvs (Archaeoglobus fulgidus), 3cin (Thermotoga maritima MSB8), 1gr0 (Mycobacterium tuberculosis) and $\mathbf{6 k 9 6}$ (Streptomyces citricolor Ari2). Secondary structural elements are annotated, active site residues are marked with an arrow and conserved residues marked with red shading (fully conserved) or pink shading (similar). 


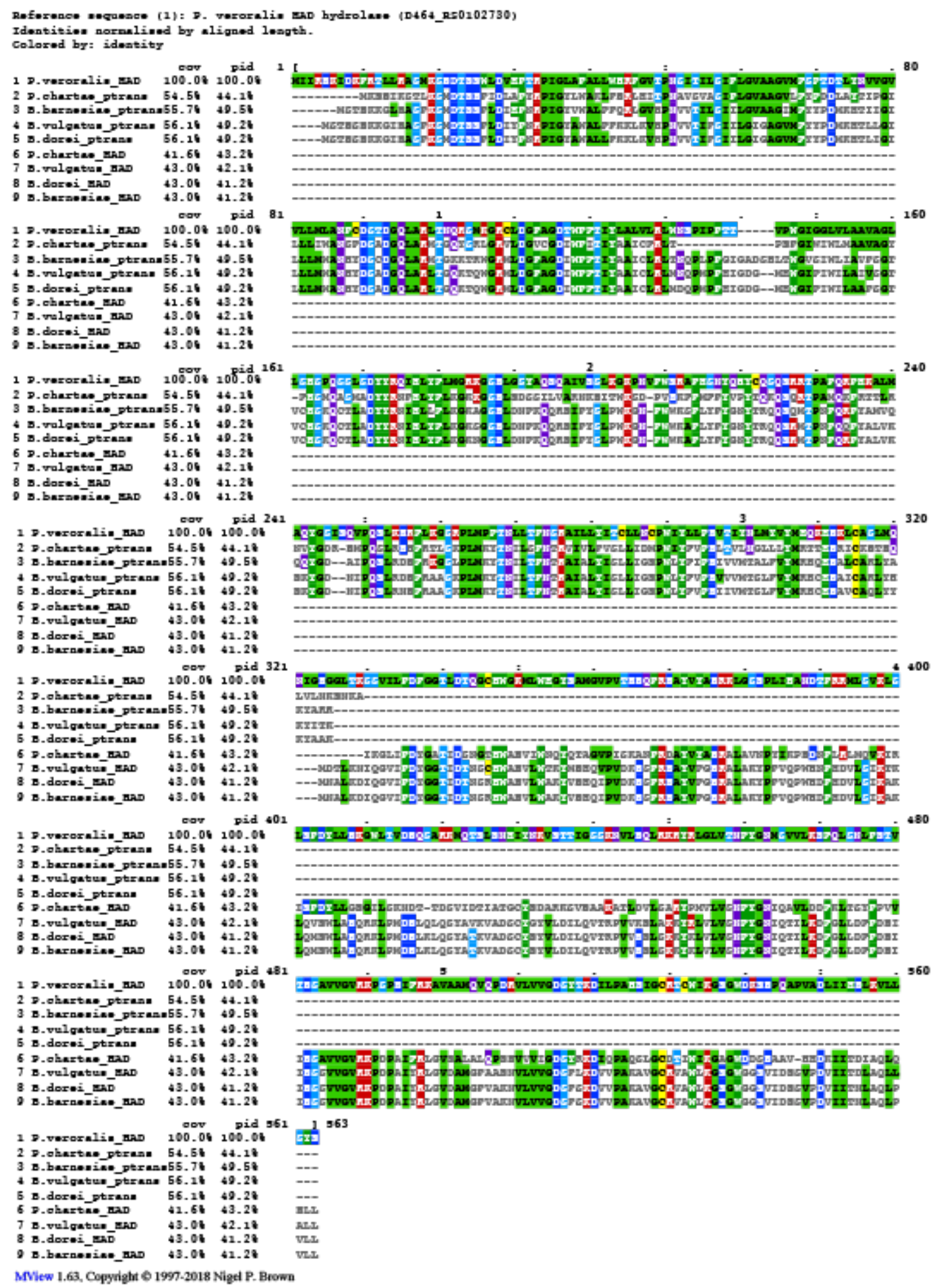

Supplementary Figure 6. Multiple sequence alignment of predicted proteins with putative involvement in an alternative inositol lipid metabolism cluster. Amino acid sequences from representative species containing the putative alternative inositol lipid metabolism cluster (Parabacteroides chartae, Bacteroides barnesiae, Bacteroides vulgatus, and Bacteroides dorei) HAD hydrolase and CDP-alcohol phosphatidyltransferase, aligned to the Prevotella veroralis predicted fusion protein with homology to both of these proteins (D464_RS0102730). Alignment was performed using Clustal Omega with visualization by MView. 
bioRxiv preprint doi: https://doi.org/10.1101/2021.04.26.441525; this version posted April 27 2021. The copyright holder for this preprint (which was not certified by peer review) is the author/funder, who has granted bioRxiv a license to display the preprint in perpetuity. It is made available under aCC-BY-NC 4.0 International license.

\section{Supplementary Tables}

Supplementary Table 1: BT_1526 (MIPS) X-ray data collection and refinement statistics.

Supplementary Table 2: Top differentially expressed genes in wild-type $B$. theta compared to the WTABT_1522 strain in minimal medium with > $1.5 \log 2 \mathrm{FC}$. Adjusted-P-value is Benjamini-Hochberg corrected.

Supplementary Table 3: Top differentially expressed genes in the iSPT strain compared to the $\triangle B T \_1526$ strain, both at $100 \mathrm{ng} / \mathrm{mL}$ aTC induction in minimal medium, with > $1.5 \log 2 \mathrm{FC}$. AdjustedP-value is Benjamini-Hochberg corrected. "CPS" column indicates the capsular polysaccharide synthesis (CPS) locus to which the gene belongs, when applicable.

Supplementary Table 4: E-values of BLAST-P homology to the $B$. thetaiotaomicron inositol lipid cluster, or the putative alternative pathway (using $B$. vulgatus sequences: phosphatidyltransferase BVU_RS13105, HAD hydrolase BVU_RS13115, NTP transferase BVU_RS13095).

Supplementary Table 5: Strains and plasmids used in this study; primers used in the amplification of genomic regions prior to plasmid assembly via restriction digest or Gibson cloning; TetR cassette components, insertion locations, primers, and gene fragment for the generation of the inducible SPT BT strain. Components and assembly were inspired by Lim et al. 2017.

Supplementary Table 6: Quantification of inositol in surface polysaccharides (raw values).

Supplementary Table 7: Kinetic data of BT_1526 MIPS (raw values). 